\title{
Evidence for hybridization and introgression in two Canadian Arctic louseworts: Pedicularis langsdorffii subsp. arctica and Pedicularis hirsuta.
}

\begin{tabular}{|r|l|}
\hline Journal: & Botany \\
\hline Manuscript ID & cjb-2015-0264.R1 \\
\hline Manuscript Type: & Article \\
\hline Complete List of Authors: & $\begin{array}{l}\text { Sokoloff, Paul; Canadian Museum of Nature, Botany Section and Centre for } \\
\text { Arctic Knowledge and Exploration } \\
\text { Chapman, Colin; Canadian Museum of Nature, Botany and Centre for Arctic } \\
\text { Knowledge and Exploration; University of Ottawa, Department of Biology } \\
\text { Gillespie, Lynn; Canadian Museum of Nature, Botany and Centre for Arctic } \\
\text { Knowledge and Exploration; University of Ottawa, Department of Biology }\end{array}$ \\
\hline Keyword: & Arctic, Pedicularis, Orobanchaceae, Hybridization, Introgression \\
\hline & \multicolumn{2}{|c|}{} \\
\hline
\end{tabular}

SCHOLARONE

Manuscripts 
Evidence for hybridization and introgression in two Canadian Arctic louseworts: Pedicularis langsdorffii subsp. arctica and Pedicularis hirsuta.

\author{
Paul C. Sokoloff ${ }^{1,3}$, Colin J. Chapman ${ }^{1,2}$, Lynn J. Gillespie $e^{1,2}$
}

1. Canadian Museum of Nature, Botany Section, Research and Collections, PO Box 3443, Station D, Ottawa, ON, K1P 6P4, Canada.

2. University of Ottawa, Department of Biology, Gendron Hall, Room 160, 30 Marie Curie, Ottawa ON, K1N 6N5, Canada.

3. Author for correspondence: psokoloff@mus-nature.ca 


\begin{abstract}
Hybridization and introgression between two closely related but taxonomically distinct Arctic lousewort species - the circumpolar Pedicularis hirsuta (predominantly eastern Arctic in Canada) and the amphiBeringian, western Canadian Pedicularis langsdorffii subsp. arctica - is documented here for the first time, only the second confirmed case of introgression in this widespread genus. Multivariate and univariate analysis of morphological characters successfully delineate the two species as morphologically similar but distinct taxa. Analysis of nrDNA ITS sequences likewise differentiate the two taxa in all sampled instances. Analysis of cpDNA atpl-atpH sequences also separate these taxa, except in 12 individuals of $P$. langsdorffii subsp. arctica, which possess the same haplotype as $P$. hirsuta. Where these two species overlap in range in the Canadian High Arctic, chloroplast transfer from $P$. hirsuta to $P$. langsdorffii subsp. arctica is detected, and morphologically intermediate hybids have been identified, indicating hybridization and subsequent backcrossing. Here we discuss the relationships between these two species, and provide a key useful in differentiating them.
\end{abstract}

Keywords: Arctic, Pedicularis, Orobanchaceae, Hybridization, Introgression 


\section{Introduction}

Pedicularis L. is the largest genus of the ca. 89 genera in the Orobanchaceae (Bennett and Mathews 2006). This widespread family, which includes many notable parasitic members, now includes ca. 73 genera (like Pedicularis) that were formerly placed in the Scrophulariaceae (Wolfe et al. 2005). With over 600 species worldwide (Robart et al. 2015), Pedicularis is most diverse in temperate Eurasia, where over 70\% of known species occur (Yang and Wang 2007). Many species can be found throughout the western hemisphere (Mill 2011), and approximately 40 are known from North America (Robart et al. 2011).

North American species of Pedicularis are thought to have radiated from Eurasian migrants (Li 1951; Robart et al. 2015). Previously, Savile (1977) suggested that up to 25 mid-latitude species on the continent evolved from a single species introduced in the Pliocene based on close morphological similarity; this is consistent wtih a recent phylogeny which estimates the number of North American ancestors to be only two (Robart et al. 2015).

Recent $r b c L$ and matK DNA barcode data for the ten species of Pedicularis occurring in the Canadian Arctic indicate deep genetic divergence among several clades, suggesting six major lineages of this genus in the region (Saarela et al. 2013). One such lineage consists of three closely-related species: Pedicularis lanata Willd. ex Cham. and Schltdl., Pedicularis hirsuta L., and Pedicularis langsdorffii Fisch. ex Steven, all with extensive ranges in the Canadian Arctic (Aiken et al. 2007; Hultén 1964; Porsild and Cody 1980). Tkach et al. (2014), in their expanded Pedicularis phylogeny (including many Arctic species omitted from previous studies), also found this "Pedicularis lanata/langsdorffii " lineage, which included P. hirsuta . In this lineage $P$. lanata forms a well-supported clade with $P$. alopecuroides Steven ex Spreng., $P$. dasyantha (Trautv.) Hadac, and P. pallasii Vved., consistent with the Pedicularis lanata aggregate in Elven et al. (2011), and Pedicularis hirsuta and P. langsdorffii are resolved as sister species (Tkach et al. 
2014). Pedicularis hirsuta is circumpolar; in North America it has a primarily eastern Arctic distribution, ranging from continental Nunavut and northernmost Quebec and Labrador, through to the eastern Canadian Arctic Archipelago and Greenland, with further occurences on Banks Island, Melville Island, and coastal Alaska (Figure 1; Aiken et al. 2007; Elven et al. 2011). Considered a rare species in Alaska, it is found at only one location along the north coast (Cortés-Burns et al. 2009).

Pedicularis langsdorffii is an amphi-beringian species with two subspecies: subsp. langsdorffii in Chukotka in Far East Russia, the Bering Sea islands, and western Alaska; and subsp. arctica (R. Br.) Pennell ex Hultén, distributed from easternmost Siberia in Russia, though northwestern North America, and across to northeastern Greenland (Figure 1; Elven et al. 2011). These two taxa were initially treated as species, P. langsdorffii (sometimes misspelled as P. langsdorfii) and P. arctica R. Br. Pedicularis arctica was treated as an infraspecific taxon within P. langsdorffii, first as a variety by Polunin in 1940, and subsequently as a subspecies (Hultén 1968); however, the species level approach continued to be widely used in Canada (e.g., Porsild 1957, Porsild and Cody 1980). Here we follow recent treatments which ascribe them to the subspecies level (Cody 2000, Elven et al. 2011). Pedicularis langsdorffii subsp. arctica, the only subspecies of $P$. langsdorffii present in Canada, is predominantly western, with a range extending from British Columbia, Alberta, Yukon and the continental Northwest Territories (and western continental Nunavut) through to Ellesmere Island in the Canadian High Arctic (Figure 1) (Porsild 1957; Porsild and Cody 1980; Aiken et al. 2007). Although these authors indicated P. langsdorffii subsp. arctica as occurring on Baffin Island, these specimens (Manning 15 CAN 204697, N. Polunin 2471 CAN 97311, Soper s.n. CAN 97308, Soper s.n CAN 97309) have since been redetermined to $P$. hirsuta, and the species is not considered present there. Both Porsild and Cody (1980) and Aiken et al. (2007) show P. I. subsp. arctica as occurring on nearby Bylot Island; however this specimen (Scotter 67143, DAO 334867) is likely a hybrid between $P$. hirsuta and $P$. I. subsp. arctica (see discussion for details) 
Though largely allopatric, their ranges overlap in several places in Canada, including northwest mainland Nunavut, northeast Banks Island, Melville Island, Bathurst Island, and notably, throughout the High Arctic on Devon, Ellesmere, and Axel Heiberg Islands (Figure 1). Both P. hirsuta (Figure 2) and $P$. langsdorffii subsp. arctica (Figure 3) exhibit similar overall morphologies - often to a degree that the plants are easily confused with each other, particularly in the southern Arctic Archipelago where $P$. hirsuta grows larger. Conversely, the species are more easily differentiated in the northern portions of their ranges, where $P$. langsdorffii subsp. arctica in turn has much larger, more colourful flowers than $P$. hirsuta (Aiken et al. 2007).

These two species have been typically differentiated from each other on the basis of two small teeth located near the tip of the galea (the fused petals forming the "helmet" on top of each flower) - with $P$. langsdorffii subsp. arctica possessing these teeth, P. hirsuta lacking them (Porsild 1957). A later treatment by Porsild and Cody (1980) separated them on the basis of inflorescence pubescence; $P$. hirsuta possessing a white-woolly inflorescence, while $P$. langsdorffii subsp. arctica appearing nearly glabrous. However, where their ranges are sympatric, morphological intermediates between these two taxa have been suggested, specifically where the two species meet on Ellesmere Island and Greenland (Porsild 1957). This may indicate that hybridization is occurring between these two taxa. Additionally, DNA barcoding has detected the matK chloroplast haplotype of $P$. hirsuta in a specimen of $P$. langsdorffii which was thought to be due to sampling a hybrid, or detection of cpDNA Introgression (Saarela et al. 2013).

Most Arctic plant species are thought to be of hybrid origin, having undergone extensive reticulation through the Pleistocene (Abbott and Brochmann 2003), and have since been stabilized through polyploidy (Brochmann et al. 2004). While previous research asserted that polyploidy, apomixis (Bliss 1971) and autogamous reproduction strategies (Savile 1964) likely lowered the potential for recent 
hybridization in Arctic plants, more current research indicates that rates of hybridization vary by taxon, and may be more prevalent than previously thought. Hybrids are noted in a diverse array of Arctic plant families, notable examples include Potentilla (Eriksen and Töpel 2006, Léveillé-Bourret et al. 2014), Papaver (Solstad 2008), Festuca (Guldhal et al. 2001), Salix (Aiken et al. 2007), Eriophorum (Cayouette 2004), and xPucciphippsia (Steen et al. 2004). As well, rates of hybridization in the Arctic may increase over time as climate change drives compatible species together (Brochmann and Brysting 2008).

Given reports of morphological intermediates between P. hirsuta and P. langsdorffii subsp. arctica where their ranges overlap, phylogenetic closeness (Saarela et al. 2013; Tkach et al. 2014), and overlapping flowering times (L.J. Gillespie, personal observation), which might enable interspecific crosspollination via pollinator sharing (Macior 1983), we hypothesize that these two sister taxa may be hybridizing where they come into contact. Here, we conduct an in-depth molecular and morphological analysis of $P$. hirsuta and $P$. langsdorffii subsp. arctica in Canada to assess their taxonomic boundaries, and evidence for hybridization and/or Introgression. 


\section{Materials and Methods}

\section{Materials Examined}

Specimens examined (Appendix A) for this study were selected to encompass the geographic range of both Pedicularis species across Canada, with a focus on regions where $P$. langsdorffii subsp. arctica and $P$. hirsuta are sympatric (Figure 1). In total, 58 specimens of $P$. hirsuta were examined; 54 were measured to collect morphological data (of which 50 specimens were used in the final analysis), and 47 specimens were DNA sequenced (only four of which did not have a corresponding voucher used in the morphology analyses). In P. langsdorffii subsp. arctica, 62 specimens were examined; 58 were measured for morphology (57 specimens in final analysis), and 49 specimens were DNA sequenced (only 7 of which did not have a corresponding morphology voucher).

\section{$\underline{P C R}$ and Sequencing}

Genomic DNA was extracted from both silica gel-preserved leaf tissue samples (50) and herbarium samples (52) according to protocols modified from Alexander et al. (2007). Not all extractions or amplifications were successful - see Appendix A for complete sample details. Pedicularis lanata, $P$. albolabiata, and P. labradorica were selected as outgroups so as to include congeners at varying phylogenetic distances (Robart et al. 2015) from the same geographic region (Porsild and Cody 1980). Samples were screened for sequence variation in $18 \mathrm{cpDNA}$ regions. The atpl-atpH intergenic spacer region (Shaw et al. 2005) was selected for further sequencing, while the following regions were rejected due to low sequence variation: the core barcode loci for vascular plants matK (Fazekas et al. 2008) and rbcL (Levin et al. 2003; Kress and Erickson 2007), trnH-psbA, trnC-rpoB, trnC-ycf6, trnD-trnT, trnS-trnG, trnS-trnfM (Shaw et al. 2005), atpB-rbcL (Chiang et al. 1998), trnT-trnL, trnL-trnF (Taberlet et al. 1991), rp32-trnL, trnV-ndhC, psbD-trnT, psbJ-petA, atpl-atpH, and petL-psbE (Shaw et al. 2005). 
For amplification of the atpl-atpH intergenic spacer, two different reaction volumes were used: $15.5 \mu \mathrm{l}$ for routine reactions, and $50 \mu \mathrm{l}$ for older and/or degraded samples. The $15.5 \mu \mathrm{l}$ reaction volumes contained 9.17 $\mu \mathrm{l}$ of $\mathrm{ddH}_{2} \mathrm{O}, 1.5 \mu \mathrm{l}$ of $10 \mathrm{X}$ reaction buffer (BioShop Canada), $1.94 \mathrm{mmol} / \mathrm{L} \mathrm{MgCl}_{2}$ (SigmaAldrich), $0.19 \mathrm{mmol} / \mathrm{L}$ dNTPs, $0.24 \mathrm{mmol} / \mathrm{l}$ of each primer at (Alpha DNA, Montreal), $0.02 \mu \mathrm{g} / \mu \mathrm{L}$ bovine serum albumin (Sigma-Aldrich), $0.08 \mu$ l of BioShop TAQ DNA Polymerase (BioShop Canada), and $1.5 \mu l$ genomic DNA. The $50 \mu \mathrm{l}$ reaction volumes contained $26 \mu \mathrm{l}$ of $\mathrm{ddH}_{2} \mathrm{O}, 5 \mu \mathrm{l}$ of $10 \mathrm{X}$ reaction buffer (BioShop Canada), $2.5 \mathrm{mmol} / \mathrm{L} \mathrm{MgCl}$ (Sigma-Aldrich), $0.2 \mathrm{mmol} / \mathrm{L} \mathrm{dNTPs,} 0.3 \mathrm{mmol} / \mathrm{L}$ of each primer (Alpha DNA, Montreal), $0.02 \mu \mathrm{g} / \mu \mathrm{L}$ bovine serum albumin (Sigma-Aldrich), $1 \mu$ l of BioShop TAQ DNA Polymerase (BioShop Canada), and $5 \mu$ l genomic DNA. Amplification reactions for both cpDNA reaction volumes were run using the same thermocycler protocols: $95^{\circ} \mathrm{C}$ for 5 minutes, 30 cycles of: $95^{\circ} \mathrm{C}$ for 45 seconds, $48^{\circ} \mathrm{C}$ for 45 seconds, $72^{\circ} \mathrm{C}$ for 1 minute 30 seconds, and a final extension step of $72^{\circ} \mathrm{C}$ for 5 minutes.

We selected the internal transcribed spacer region (ITS) of the nrDNA for sequencing to assess variation using a nuclear marker (and to compare with the plastid data). We used the ITS1 and ITS4 primers described in White et al. (1990) to amplify and sequence the entire region. For the ITS PCRs, each 15.5 $\mu$ l reaction volume contained $6.87 \mu$ l of $\mathrm{dd}_{2} \mathrm{O}, 1.5 \mu \mathrm{l}$ of $10 \mathrm{X}$ reaction buffer (BioShop Canada), 2.41 $\mathrm{mmol} / \mathrm{L} \mathrm{MgCl}$ (Sigma-Aldrich), $0.19 \mathrm{mmol} / \mathrm{L}$ dNTPs, $0.24 \mathrm{mmol} / \mathrm{L}$ of each primer (Alpha DNA, Montreal), $0.02 \mu \mathrm{g} / \mu \mathrm{L}$ bovine serum albumin (Sigma-Aldrich), $0.08 \mu$ of BioShop TAQ DNA Polymerase (BioShop Canada), and $1.5 \mu$ l genomic DNA. The ITS PCRs were run using the following thermocycler protocols: $94^{\circ} \mathrm{C}$ for 3 minutes, 35 cycles of: $94^{\circ} \mathrm{C}$ for 1 minute, $42^{\circ} \mathrm{C}$ for 1 minute, $72^{\circ} \mathrm{C}$ for 1 minute 20 seconds, and a final extension step of $72^{\circ} \mathrm{C}$ for 5 minutes.

PCR products were purified by adding $6 \mu$ l of a 1:10 dilution of ExoSAP $(1 \mu$ l of Exonuclease I [MJ

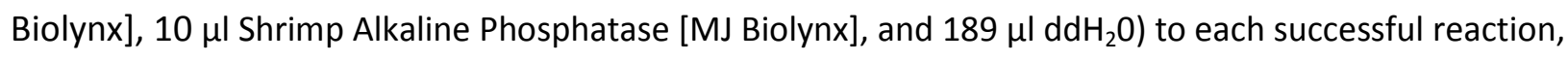


and incubating the mixtures at $37^{\circ} \mathrm{C}$ for 30 minutes, followed by 10 minutes at $90^{\circ} \mathrm{C}$. Purified PCR products were sequenced on an ABI 3130xI Genetic Analyser using BigDye version 3.1 chemistry (Applied Biosystems). Sequence traces were assembled, visually verified, and aligned in Genious 6.0.3 using the ClustalW alignment method (Biomatters).

\section{$\underline{\text { Phylogenetic Analysis }}$}

Models for nucleotide substitution were determined using the Akaike Information Criterion, calculated using MrModetest2 (Nylander 2004). For the atpl-atpH dataset the HKY+I model was selected, and for the ITS dataset the GTR+G model was chosen. There was no indel variation between or within $P$. hirsuta or P. langsdorffii subsp. arctica; accordingly indel characters were not included in our analysis.

Each marker (atpl-atpH and ITS) was analyzed separately. Bayesian analysis was run on each dataset in MrBayes 3.2.2 (Ronquist et al. 2012). In each analysis, two Markov chains were run for 20000000 generations, with trees sampled after every $100^{\text {th }}$ generation, and 5000 trees discarded as the burn-in. Results were summarized as a majority rule consensus tree.

Maximum parisimony analyses were carried out in PAUP 4.0 (Swofford 2003) by running a heuristic search algorithm using the following parameters: 1000 replicates run to completion using random stepwise addition sequence and tree bisection reconnection (TBR) branch swapping. This resulted in 204 equally parsimonious trees for the ITS dataset and 24 equally parsimonious trees for atpl-atpH dataset, from which a strict consensus tree was generated for each dataset. Bootstrap support was obtained in PAUP 4.0 using the following parameters: 100 bootstrap replicates with a maximum of 10 000 trees generated per replicate through simple stepwise addition sequence and TBR branch swapping (Swofford 2003).

Morphology 
A set of 32 characters were selected based on keys and descriptions of $P$. hirsuta and $P$. langsdorffii subsp. arctica from both Arctic floras and primary literature sources (Hultén 1968; Porsild 1955, 1957; Savile 1964, 1977; Welsh 1974; Aiken et al. 2007; Porsild and Cody 1980; Cody 2000; Robart 2005). These included 30 quantitative, and two qualitative characters (Table 1). Quantitative characters were directly measured using a ruler and digital calipers (Table 1; Figure 4). Qualitative characters (stem and inflorescence pubescence) were visually scored into six discrete character states: glabrous (no visible hairs on observed surface), glabrate (few hairs distributed sporadically over surface), sparse (approx. one to five hairs evenly distributed per $\mathrm{cm}^{2}$, outer epidermis clearly visible under hairs), moderate (approx. 10-20 hairs evenly distributed per $\mathrm{cm}^{2}$, outer epidermis partially hidden under hairs), dense (hairs covering surface, outer epidermis only partially visible under hairs), and very dense (surface completely covered in dense, wooly pubescence, outer epidermis completely hidden) (Table 1).

Four fruiting specimen characters (fruit width, fruit length, seed width, and seed length) were ultimately omitted due to missing data; fruiting specimens were rarely encountered in our herbarium search. As they seem to be infrequently collected, we did not find enough clearly identifiable specimens to analyze. Accordingly, specimens without flowers were omitted from the final multivariate analysis (Appendix A).

A total of 107 specimens (excluding fruiting specimens) from across the range of these taxa in the Canadian Arctic were measured. Based on measurements of key characters and our multivariate analysis (elaborated on in Results), 50 specimens were identified as $P$. hirsuta, 50 as $P$. langsdorffii subsp. arctica, and 7 specimens previously identified as $P$. I. subsp. arctica were identified as putative hybrids with intermediate or shared diagnostic characters from both species. These putative hybrids were omitted from both our univariate statistical analysis (though their measurements are included in Table 1) and our analysis of stem and inflorescence pubescence. 
Three principal components analyses (PCA) were carried out on the data collected from the 26 remaining continuous variables in PAST 3.01 (Hammer et al., 2001); one PCA retaining just the 12 floral characters, one retaining the 14 vegetative characters, and one with all 26 characters.

Quantitative variables were tested for interspecific variation between the two taxa, excluding the putative hybrids, using a Mann-Whitney $U$ test (as the data were not normally distributed) in PAST. We recorded the Mann-Whitney $\mathrm{U}$ statistic, the $\mathrm{Z}$ statistic, and the $\mathrm{p}$ value for these tests, and assessed their significance at the $p<0.05$ and $p<0.001$ levels. Median values and standard deviations for these variables were recorded and compared using boxplots.

Qualitative variable scores were transformed into percentages of specimens examined displaying each of six discrete character states for pubescence (Table 1), and charted using a stacked column chart. 


\section{Results}

Phylogenetic Analysis

Analysis of both the nuclear (ITS) and plastid (atpl-atpH) datasets show that Pedicularis hirsuta and Pedicularis langsdorffii subsp. arctica resolved together in a strongly supported clade, well separated from the outgroups, $P$. lanata, $P$. albolabiata, and $P$. labradorica, confirming that these two species are more closely related to each other (Figures 5,6 ). This clade resolved as sister to $P$. lanata (Figure 5).

Both maximum parsimony and Bayesian analysis of the ITS dataset (both trees possessed identical topology) show that $P$. hirsuta and $P$. langsdorffii subsp. arctica were each well resolved as a separate clade, with posterior probability scores of 0.73 and 0.68 and high levels of bootstrap support (92 and 98) respectively (Figure 5). There was no genotypic variation or geographic structuring in the two studied species: all specimens of $P$. hirsuta and $P$. langsdorffii subsp. arctica displayed the same ITS genotype respectively.

Pedicularis hirsuta specimens display a genetically uniform haplotype and cluster together in analyses of the atpl-atpH dataset, differentiated from the majority of $P$. langsdorffii subsp. arctica haplotypes with a posterior probability of 0.83 and a bootstrap value of 88 (Figure 6). Pedicularis langsdorffii subsp. arctica possesses a variety of distinct haplotypes with all differentiated from P. hirsuta except for 12 specimens from Ellesmere, Banks, Devon, Melville, and Axel Heiberg Islands in the Canadian High Arctic and western Arctic islands (Figure 1, introgressed specimens), 11 of these 12 specimens possessed the same, and one a very similar haplotype as $P$. hirsuta. Most $P$. langsdorffii subsp. arctica haplotypes were not resolved in the Bayesian analysis, thus we present the maximum parsimony tree here (Figure 6).

\section{Morphology}


Principal components analysis of the 12 floral morphological variables show both $P$. hirsuta and $P$. langsdorffii subsp. arctica as distinct clusters in multivariate space (Figure 7). The P. langsdorffii subsp. arctica specimens possessing a $P$. hirsuta haplotype (introgressed) exclusively cluster with $P$. langsdorffii subsp. arctica. PCA of the full 26 character dataset showed the same pattern as the floral dataset while explaining less of the variation in the data, and PCA of the 14 vegetative characters showed total overlap between the two taxa (Supplementary Figure S1). Specimens forming a third cluster (discussed in detail below), intermediate between the two species, were identified as putative hybrids.

Univariate analysis of the 12 continuous floral morphology variables measured indicate that, in general, the flowers of Pedicularis langsdorffii subsp. arctica are larger and more robust than flowers of $P$. hirsuta. There are significant differences between the two taxa for 11 of the 12 measured variables; for all of these variables P. I. arctica possessed the higher median value (Figure 8 , Table 1). Only calyx short sepal length was not significantly different (Figure 8 , Table 1). Notably, there was zero style protuberance in all $P$. hirsuta specimens measured, as opposed to a median length of $1.1 \mathrm{~mm}$ in $P$. langsdorffii subsp. arctica. Of the 14 vegetative characters measured, cauline leaf blade width, cauline leaf petiole length, cauline leaf lobe length, cauline leaf lobe width, bract blade width, and bract petiole length were all significantly different between the two taxa (Supplementary Figure S2, Table 1).

The vast majority of $P$. hirsuta specimens displayed dense inflorescence pubescence (85\%), versus the nearly even split of sparse and moderate (and about 20\% dense) character state proportions seen in $P$. langsdorffii subsp. arctica (Figure 9a). Both P. hirsuta and P. langsdorffii subsp. arctica have similar distributions for the stem pubescence qualitative character states, with mostly similar proportions of specimens displaying glabrate, sparse, and moderate stem pubescence; $P$. hirsuta possessed a higher 
proportion of plants with moderately pubescent stems, and $P$. I. subsp. arctica has a higher proportion with glabrate stems. (Figure 9b).

Seven specimens, four from the Truelove lowlands on Devon Island (Mackenzie 14, Mackenzie 21, Mackenzie 45, and Pakarinen s.n. [CAN 409449]), one from the Fosheim Peninsula on Ellesmere Island (Gillespie 6138), one from Tanquary Fjord on Ellesmere Island (Gillespie 6478), and one from Mokka Fjord on Axel Heiberg Island (Parker 73061A) were found to have intermediate morphology in both the floral and combined PCAs (Figure 7, Supplementary Figure S1a). The four Truelove Inlet individuals all possessed short, densely hirsute racemes, short calyces (both lengths), short distances from the tip of the galea to the teeth, and short corollas (all approaching $P$. hirsuta), wide corolla lips (approaching $P$. I. subsp. arctica), and intermediate anther length and intermediate galea width (Table 1). In this population both length of protruding style and tooth length were observed to be variable on the individual flowers of a single plant, and among different plants on the same herbarium sheet - ranging from non-exserted to extremely long-exerted styles, and calyx teeth ranging from absent to long, even on a single plant. Likewise exserted styles varied in orientation, from straight and perpendicular to the galea (as in P. I. subsp. arctica), to moderately-to-strongly recurved exserted styles (approaching the strongly recurved non-exerted styles of $P$. hirsuta). These plants all shared the same overall appearance, approaching an intermediate form between the two taxa, with the compact inflorescences and hirsute racemes characteristic of $P$. hirsuta, and the protruding styles (Table 1 ) characteristic of $P$. I. subsp. arctica.

The putative hybrid specimen from the Fosheim Peninsula (Gillespie 6138) also possessed variation in teeth presence and length, and style length, exsertion, and orientation, similar to the Truelove Inlet population. Morphologically, this specimen possessed narrow corolla lips, short corollas, and short galea teeth (all characters closer to the median values observed in P. hirsuta), and long anthers, longer 
distances from the galea tip to the galea teeth, and wide galeas (closer to P. I. subsp. arctica) (Table 1). The other Ellesmere specimen from Tanquary Fiord (Gillespie 6478) possessed long corollas, wide galeas, well-exserted, erect styles, and long anthers characteristic of $P$. I. subsp. arctica, the short raceme, short calyies, and short (and sometimes absent) galea teeth characteristic of $P$. hirsuta, and intermediate measurements for lip width and galea teeth distance from tip (Table 1). The last specimen, Parker 73061A from Mokka Fiord, possessed short inflorescences, narrow corolla lips, and short (and sometimes absent) galea teeth (all character states approaching $P$. hirsuta), wide calyces, wide galeas, long anthers, exserted styles (all character states approaching $P$. I. subsp. arctica), and styles of variable orientation and intermediate corolla lengths (Table 1).

Of these seven putatively hybrid specimens, only one (Mackenzie 21) from the Truelove lowlands was included in our genetic analyses, where it was found to possess the nuclear genotype of $P$. langsdorffii subp. arctica, and the plastid haplotype of $P$. hirsuta (Figures 5, 6- recorded on these figures as $P$. langsdorffii subsp. arctica GIL2433 Devon). Another individual from the Truelove lowlands (Kerik 40, P. langsdorffii subsp. arctica GIL2418 Devon on Figures 5 and 6), identified as (non hybrid) P. langsdorffii subsp. arctica, and determined to be introgressed, was located well within the $P$. langsdorffii subsp. arctica polygon in our PCA (Figure 7). 


\section{Discussion}

Our analysis of the Pedicularis hirsuta/Pedicularis langsdorffii subsp. arctica species complex indicates that these two species are taxonomically distinct entities, as supported by both molecular (Figure 5) and morphological (Figure 7) evidence. However, putative morphologically intermediate hybrids have been identified from their points of contact in the Canadian Arctic (Figure 7), and introgression between the two species has been detected at these points of contact through comparison of our chloroplast and nuclear DNA datasets (Figures 5, 6).

Taxonomic status and distinguishing characters of Pedicularis hirsuta and Pedicularis langsdorffii subsp. arctica in North America

Though there is clear evidence for hybridization and introgression in this group, our data indicates that these two largely allopatric species are distinct, though closely related entities. Analysis of the ITS sequences we generated clearly differentiates $P$. hirsuta from $P$. langsdorffii subsp. arctica (Figure 5). The same pattern is seen in the analysis of the chloroplast atpl-atpH sequences, save for the introgressed individuals (Figure 6).

Morphologically, when the putative hybrids are excluded, principal components analysis of the floral character matrix shows clear separation between the two taxa, with no overlap in multivariate space (Figure 7). This separation was driven by the eleven significantly different inflorescence characters measured between clearly identifiable, non-hybrid individuals for each taxon (Figure 8, Table 1).

These floral traits are consistent with Pennell's work on North American Pedicularis (1935), which is reliant on corolla and calyx characters in differentiating taxa. This was also noted in Aiken et al. (2007): “... the unusually large, dark purple, conspicuously spreading and clearly bidentate flowers of the far northern plants identify them with $P$. langsdorffii." when referring to confusion in differentiating $P$. 
hirsuta from $P$. langsdorffii subsp. arctica (which they synonymized under $P$. langsdorffii). Böcher et al. (1968) also noted the large purple corollas of $P$. langsdorffii and the smaller pink corollas of $P$. hirsuta as useful distinguishing characters. Though we did not score flower color (very few dried specimens of either species retained their corolla colour), field observations (L.J. Gillespie) and floristic treatments (Porsild 1957; Böcher et al., 1968; Porsild and Cody 1980; Aiken et al. 2007) report a generally paler corolla in P. hirsuta when compared to P. langsdorffii subsp. arctica. Certainly our findings support the assertions of Böcher et al. (1968) and Aiken et al. (2007) of larger flowers, primarily statistically longer corollas, wider galeas, and wider corolla lips in P. langsdorffii subsp. arctica than in P. hirsuta (Figure 8). The length of the raceme (inflorescence length: Figure 8) was also found to be statistically longer in P. langsdorffii subsp. arctica than in P. hirsuta. Although inflorescence, corolla, and calyx size characters were found to be statistically significant between the two taxa, they cannot be used alone to distinguish the species due to the often large overlap (Figure 8).

Style protuberance and anther length were found to be the best diagnostic characters, since they had no or very little overlap, respectively, between the two taxa. Style protuberance, which was previously used to differentiate the taxa in Greenland (Böcher et al. 1968), was found to be exceptionally useful (Figure 8), as the style never protrudes from "good" P. hirsuta (Figure 2) - only P. langsdorffii subsp. arctica displays any style protrusion (Figures 3,8 ). Anther length was found to be an excellent diagnostic character (Figure 8; 0.9-2.0 mm in P. hirsuta, 2.0-3.0 mm in P. langsdorffii subsp. arctica), and one that has not been used previously.

Our findings on floral morphology in each species - small, duller colored flowers with smaller anthers and retracted styles in P. hirsuta, and larger, brightly colored flowers with large anthers and protruding styles in P. langsdorffii subsp. arctica - is consistent with the pollination syndromes previously observed in these species. Pedicularis hirsuta is structurally adapted for self-pollination (Swales 1979), and was 
found to have high reproductive success despite rare pollination events (Eriksen et al. 1993). Studies in West Greenland showing high seed set when pollinators were excluded (Philipp et al. 1996) and no variability in seven isozyme systems studied (Philipp 1998) also provide evidence for $P$. hirsuta as highly self-pollinating. Conversely, P. langsdorffii subsp. arctica exhibits high reproductive success when insect pollinated - the large corolla lip, large anthers, and protruding style seem adapted for just this purpose (Williams and Batzli 1982). Macior (1975), in his studies of this species in the Yukon, determined that pollinators were almost exclusively bumblebees collecting both pollen and nectar, and that plants did not set seed in the absence of pollinators. Selfing versus outcrossing pollination syndromes may serve to reinforce species boundaries in this complex, but may also partially explain the hybridization and unidirectional chloroplast capture we observed, as we discuss below.

Fewer vegetative characters differed significantly (and most only at the $p>0.5$ level) between the two taxa; these include cauline leaf blade width, cauline leaf lobe length and width, inflorescence bract blade width, bract petiole length ( $p>0.01$ ), and stem width (Suppl. figure S2, Table 1). Previous work has indicated that vegetative structures are conserved in Pedicularis, and are less variable and less useful when compared to floral structures (Li 1951). Savile (1977) hypothesized that the similar leaf morphologies seen in Canadian Arctic Pedicularis species were derived from a single mid-latitude alpine species through population isolation in the Pleistocene; the pinnatifid leaves were conserved in Arctic species and suggested to be not a disadvantage in open sites. Altogether, we found floral characters, and not vegetative characters, to be useful in distinguishing $P$. hirsuta and $P$. langsdorffii subsp. arctica.

Prior to this study, there have been differences in opinion and some confusion on the taxonomic boundaries and morphological traits distinguishing $P$. hirsuta from $P$. langsdorffii subsp. arctica (Simmons 1906; Hultén 1964; Polunin 1940; Porsild 1957; Porsild and Cody 1980). For example, Hultén (1964) used basal leaf breadth, filament hair density, and galea teeth to separate these species. While 
galea teeth are easily observed and measured, filament hair density requires flowers collected when fully open, and basal leaves are rarely seen on herbarium sheets of these two species. This galea teeth character is one of two often cited characters used to distinguish these two species in the above mentioned treatments, the other being stem and inflorescence pubescence.

Porsild (1957) described $P$. hirsuta as lacking teeth on the galea, distinguishing it from teeth-bearing $P$. langsdorffii subsp. arctica. Böcher et al. (1968) also used the presence of galea teeth - though he qualified P. hirsuta as "usually without teeth" (pg. 163) - as a diagnostic character useful in differentiating the two species in Greenland. Our examination of the species complex found that typical P. hirsuta flowers do possess a pair of teeth on the galea; however, they are significantly shorter and closer to the distal tip of the corolla when compared with P. langsdorffii subsp. arctica (Figure 8, Table 1). This is consistent with Hultén (1964 - pg. 312), who asserted that $P$. hirsuta had "a less distinct tooth of the galea". Even though both species bear teeth on the galea, our results indicate that the length of the teeth and their distance from the corolla tip are useful characters for differentiating these sister species, similar to their use in other members of Pedicularis (Li 1948).

Another previously unclear taxonomic character is the pubescence on the stem and surrounding the inflorescence in these two species. Previous work by Porsild and Cody (1980) suggested that the stem and inflorescence of $P$. langsdorffii subsp. arctica were glabrous or nearly so while in $P$. hirsuta they were "white-wooly". Later, Cody (2000) also described the inflorescence of Yukon P. langsdorffii subsp. arctica as essentially glabrous. Our qualitative examination of the species complex showed that the stem and inflorescence of $P$. hirsuta were indeed frequently densely hairy, but very few of the $P$. langsdorffii subsp. arctica specimens were completely glabrous. Overall, stem pubescence showed similar levels of density for both species, but $P$. hirsuta possessed a greater number of specimens with very hairy inflorescences. While some variation in the amount of hair is likely due to phenotypic plasticity, the 
higher density of hair on the inflorescence in P. hirsuta allows for it to be retained as a distinguishing character.

Combining the two diagnositic characters, style protuberance and anther length, with the statistically significant flower and inflorescence size characters allows us to create a key useful for separating these taxa. Of the many different keys in the literature, each focusing on a single or a set of different characters, the key of Böcher et al. (1968), which used style protruberance, corolla size, and corolla colour, best differentiated the two taxa.

Key to Pedicularis hirsuta and Pedicularis langsdorffii subsp. arctica in Canada

Style not protruding from tip of corolla galea; anthers 0.8-2.0 mm long; galea teeth absent or short (0$0.3(-0.5) \mathrm{mm}$ long), 0-0.8 (-1.1) $\mathrm{mm}$ from tip of galea; corolla pale pink, small (8.0-16.0 (-19.0) $\mathrm{mm}$ long, lip 3.0-10.0 mm wide); inflorescence usually shorter (14-47 (-160) $\mathrm{mm}$ long), moderately to densely hairy; primarily eastern Arctic species, common in Nunavut (Figure 2).

Pedicularis hirsuta

Style protruding $0.5-3.0 \mathrm{~mm}$ from tip of the corolla galea; anthers $2.0-3.2 \mathrm{~mm}$ long; galea teeth longer ((0.1-) 0.2-0.7 (-1.0) $\mathrm{mm}$ long), 0.5-1.8 $\mathrm{mm}$ from tip of galea; corolla deep pink to purple, larger (11.0)16.0-26.0 mm long, lip (5.0-) 7.0-19.0 mm wide), inflorescence usually longer ((24) 40-100 (-180) mm long), glabrate to moderately hairy (rarely densely hairy); primarily western Arctic species, common in the Northwest Territories, Yukon, northern and western Nunavut (Figure 3).

Pedicularis langsdorffii subsp. arctica

\section{Phylogeography of Pedicularis hirsuta and Pedicularis langsdorffii subsp. arctica}

The genetic variation observed within the cpDNA atpl-atpH sequences is similar to patterns seen in previous studies on Arctic plant evolution and phylogeography in North America (Tremblay and Schoen 1999; Abbott and Brochmann 2003; Eidesen et al. 2007): a genetically diverse taxon (P. langsdorffii subsp. arctica) centered on unglaciated Beringia, and a genetically-uniform taxon ( $P$. hirsuta) with a Canadian centre of distribution in the glaciated Arctic Islands (Figures 1, 6). Pedicularis langsdorffii subsp. arctica likely spread from Beringia across the western Arctic islands and High Arctic after the last 
glaciation. The observed cpDNA variation in this species did not have an obvious geographical component; high diversity in the western Arctic islands may suggest survival in refugia in situ (Tremblay and Schoen 1999; Fedorov and Stenseth 2002), however equally high diversity in the much less sampled western Arctic mainland suggests migration from Beringia. Based on geographic area analysis of multiple Pedicularis species, Robart et al. (2015) suggested an ancestral area in the Cascade Range and/or southern Rocky Mountains and subsequent continental glacial advance and retreat to explain the origin and biogeographic patterns of several Arctic species, including P. langsdorffii. Comprehensive sampling across its range with a focus on Beringian and alpine populations is needed to more adequately study the phylogeography of this species. The genetically uniform $P$. hirsuta obviously migrated to the Canadian Arctic from ice-free refugia after the last glaciation, however where these refugia were located is not evident from our data. One hypothesis is that $P$. hirsuta evolved from the $P$. langsdorffii subsp. arctica populations sheltered in the Beringian refugium (Abbott and Brochmann 2003) after the glaciers receded; however equally likely is an older origin and survival in refugia south of the ice sheet in North American and/or Eurasia Comprehensive sampling across its circumarctic range would be necessary to address these hypotheses.

Hybridization of Pedicularis hirsuta and Pedicularis langsdorffii subsp. arctica

While the above key is based on clearly identifiable, non-hybrid individuals from each taxon, we did identify morphologically intermediate specimens from Axel Heiberg Island, Ellesmere Island, and Devon Island (see results). Based on their shared and intermediate character states (which are not necessarily the same between populations), and their intermediate, non-overlapping cluster in multivariate space, we have identified these specimens as putative hybrids. 
The population of putative hybrids at Truelove Inlet on Devon Island all possessed character traits that marked them as a population of relatively uniform hybrids, including intermediate anther lengths and galea widths, and hybrid styles of variable exsertion, length, and orientation. This style could be interpreted as a type of intermediate character: in P. hirsuta, the style is long and strongly recurved, but is never exserted from the galea, whereas the style in P. langsdorffii subsp. arctica is always straight and exserted from the tip of the galea at a right angle. The Truelove Inlet styles exhibited a wide range of character states; some were not exserted at all, some were exserted as in P. langsdorffii subsp. arctica, and some were recurved and exserted from the galea. This latter character state may represent a cross between the recurved, not exserted and straight, exserted styles. These recurved but exserted styles were also present in one of the other three identified putative hybrids (Gillespie 6138), but not in the other two (Gillespie 6478, and Parker 73061A). These three collections are all clearly identifiable as hybrids based on our multivariate analysis and on different suites of character states intermediate between and shared with the two parents.

Saarela et al. (2013) discussed two putative hybrids between P. hirsuta and P. langsdorffii subsp. arctica based on observed discrepencies in matK and $r b c L$ sequence data. Though we did not include these specimens in our morphology analyses, we did locate these specimens and identify one as an introgressed individual of $P$. langsdorffii subp. arctica, and the other as a putative hybrid6. The former, Gillespie and Vogel 6105 from Axel Heiberg Island, possessed the matK haplotype of $P$. hirsuta, but was observed to possess the wide galeas, long galea teeth, long anthers, and wide corolla lips characteristic of $P$. langsdorffii subp. arctica.

The latter, Gillespie and Vogel 6218 (but mistakenly referred to as Gillespie 5218 in Saarela et al. 2013) from Lake Hazen, Ellesmere Island, was found to possess intermediate morphology, a plastid haplotype (matK) shared with $P$. hirsuta (Saarela et al. 2013), and the nuclear haplotype of $P$. I. subsp. arctica 
(Figure 5, as GIL_2588), consistent with our previously identified putative hybrids. These characters included small anthers (1.6-2.0 mm long) and short galea teeth $(0.3-0.5 \mathrm{~mm})$, both character states closer to $P$. hirsuta, and long corollas (13.0-16.0 mm long), a P. langsdorffii subp. arctica trait. Notably, this specimen possessed exserted styles of varying lengths, many of which were very long and recurved, a trait observed in the putative hybrid population at Truelove Inlet.

Additionally, we identified one potential hybrid specimen from Bylot Island, Nunavut, after we completed our data analysis. This specimen (Scotter and Zoltai 67143, DAO 334867), previously identified as $P$. I. subsp. arctica, possessed the larger stature and larger flowers of $P$. langsdorffii subsp. arctica, the hirsute inflorescences of $P$. hirsuta, and the sometimes-exserted, recurved styles identified as a hybrid character above. This specimen may in fact represent an eastern limit of the hybrid zone between these two taxa. Although Porsild (1957) mentioned intermediate forms on Baffin Island, we have identifed neither "good" P. I. subsp. arctica nor hybrid specimens from there; however, this specimen from Bylot Island, adjacent to the north coast of Baffin Island, is geographically close. Hybridization has previously been documented in temperate and boreal Pedicularis species, including ten species of European Pedicularis (Hegi 1909). Macior (1975) previously noted the possibility of hybridization in Pedicularis in the Yukon, specifically between P. lanata (as P. kanei Durand) and P.langsdorffii based on shared pollinators, and partial fertility in artificial crosses between the species. Both P. langsdorffii and P. hirsuta are diploids, 2n=16 (Zhukova 1966, Hedberg 1967), so ploidy would not likely hinder hybridzation. Compellingly, our putative hybrids were only found where both taxa came into contact (with the possible exception of the Bylot Island specimen discussed above) (Figure 1), and where introgressed individuals of $P$. langsdorffii subsp. arctica (as discussed below) have been detected; this supports our assertion that these eight specimens (including Gillespie and Vogel 6218) are hybrid individuals. 
Evidence for Introgression between Pedicularis hirsuta and Pedicularis langsdorffii subsp. arctica

The presence of the $P$. hirsuta plastid haplotype in "good" P. langsdorffii subsp. arctica (i.e., their identity is supported by both morphology and ITS sequence data), and the detection of morphologically intermediate hybrids is strong evidence for hybridization, gene flow, and chloroplast introgression between the two taxa (Soltis et al. 1992). Introgression was recently described for the first time for this genus in Tibetan species of Pedicularis sect. Cyathophora by Eaton and Ree (2013), who detected recurrent introgression and reticulation between nearly all members of this clade - significantly affecting phylogenetic inference. Introgression has also been detected in Rhinanthus - another member of the Orobanchaceae (Ducarme and Wesselingh 2005).

Introgression happens when two taxa hybridize, and the hybrid backcrosses with the paternal parent, "capturing" the chloroplast of the maternal parent in subsequent offspring. Over evolutionary time these lineages remain taxonomically distinct from one other - subsequent hybridization between the taxa is rare - and the result is two stable species, with one possessing a chloroplast inherited from the other through these introgression events (Harrison and Larson 2014). Introgression has been previously documented in the Canadian Arctic Archipelago in Poa hartzii (Gillespie et al. 1997; Gillespie and Boles 2001), and suggested in some Canadian populations of the circumpolar legume Astragalus eucosmus (Sokoloff and Gillespie 2012).

Introgression may fit one of two patterns: localized or dispersed (Rieseberg and Brunsfeld 1992). In the former scenario, chloroplast capture occurs within a highly localized hybrid swarm, with extensive reticulation and morphological intermediates confined to a specific geographic area. This pattern is commonly seen in sympatric species (Rieseberg and Brunsfeld 1992). While both $P$. hirsuta and $P$. langsdorffii subsp. arctica are allopatric at the eastern and western parts of their ranges respectively (Figure 1), they may be considered sympatric where they come into contact in the north central 
Canadian Arctic Archipelago, given their similar habitat preferences (moist tundra, riverbanks and pond edges) (Aiken et al. 2007), and previous collections of both species from the same site, notably on Ellesmere Island (Soper and Powell 1985).

Though these sympatric zones weren't directly observed for the purposes of this study, morphologically intermediate specimens (as mentioned in Porsild 1957) were encountered during examination of the herbarium specimens, namely on Axel Heiberg Island, Ellesmere Island, and Devon Island. Specimens from the Truelove lowlands, Devon Island - the only site where we identified multiple hybrid specimens (multiple plants on four herbarium sheets) - shared two putatively hybrid character states (intermediate anther length and galea width), while other character states (style protuberance, galea teeth presence/length) were variable within the population. This may indicate that this first pattern of introgression, hybrid swarming, is happening at this location. Notably, one morphologically "good", introgressed $P$. langsdorffii subsp. arctica (Kerik 40) was identified at the same site - an indication that backcrossing and chloroplast capture (as discussed below) is occurring at this site as well.

In the second pattern of introgression described in Rieseberg and Brunsfeld (1992), dispersed introgression, gene flow occurs between two species from their point of contact - after the initial hybridization, backcrossing occurs preferentially with one of the two parents, giving rise to chloroplast capture in taxonomically "good" species - i.e., the chloroplast genome of one parent in a plant with the nuclear genome and morphotype of another (Rieseberg and Brunsfeld 1992).

This pattern was observed at multiple points of contact between $P$. hirsuta and $P$. langsdorffii subsp. arctica; these introgressed individuals ( $P$. langsdorffii subsp. arctica specimens that exhibited the $P$. hirsuta cpDNA haplotype) were only found where the two species met in the Canadian High Arctic and western Arctic islands (i.e., Ellesmere Island, Devon Island, Axel Heiberg Island, Melville Island, Banks Island). 
Under this model, backcrossing is generally unidirectional (Soltis et al. 1992). Ducarme and Wesselingh's work (2005) found unidirectional introgression into Rhinanthus angustifolius from Rhinanthus minor. They hypothesised that the direction of introgression could be influenced by several factors. The direction of most frequent crosses, the relative abundance of the different species, as well as other environmental conditions were suggested as playing a part in directing the evolution of mixed populations.

Based on our molecular and morphological evidence, pollination syndromes and floral morphology are likely the major drivers of unidirectional chloroplast introgression from P. langsdorffii subsp. arctica into P. hirsuta. As mentioned previously, P. langsdorffii subsp. arctica is structurally well adapted for outcrossing (Willams and Batzli 1982), and P. hirsuta is observed to be predominantly selfing (Eriksen et al 1993; Phillip 1998). Therefore, P. hirsuta would be less likely to be the pollen source and more likely to receive pollen from $P$. langsdorffii subsp. arctica (simply due to more pollinators visiting the latter species) and become the maternal parent of an $\mathrm{F}_{1}$ hybrid. A pollinator visiting such a $P$. langsdorffii subsp. arctica $\times P$. hirsuta hybrid (with $P$. hirsuta as the maternal parent) likely would be carrying $P$. langsdorffii subsp. arctica pollen having previously preferentially visited this species based on its pollinator-adapted flowers. This pattern, supported by our molecular evidence, suggests that all subsequent reproduction was likely entirely with members of $P$. langsdorffii subsp. arctica as the pollen parent, resulting in transfer of the $P$. hirsuta chloroplast into $P$. langsdorfii subsp. arctica. Conversely, the selfing-adapted flowers of $P$. hirsuta and fewer pollinator visits reduces the likelihood that this species would provide pollen, and additional nuclear genetic material, in backcrosses with the hybrids. 


\section{Acknowledgements}

We are grateful to Shan Leung for screening cpDNA regions for variability within the study group, and to Roger Bull for continued assistance with DNA extraction, amplification, sequencing, and data processing. We would like to thank the staff of the National Herbarium of Canada (CAN) - Jennifer Doubt, Micheline Beaulieu-Bouchard, and Laura Smyk - for access to specimens and assistance with sampling. Comments from Warren Cardinal-McTeague, and David Carpenter on earlier drafts, and from two anonymous reviewers were greatly appreciated. Thanks go to Alan MacDonald, who assisted with figure formatting. We gratefully acknowledge the Polar Continental Shelf Program for logistical support of fieldwork in the Canadian Arctic, and the Canadian Museum of Nature for financial support (funding to LJG). 


\section{Author Contributions}

Conceived and designed the study: LJG CCC PCS. Gathered data: CCC PCS. Analyzed the data: PCS CCC..

Interpreted the data: LJG PCS CCC. Wrote the manuscript: PCS CC. Commented on and edited the manuscript: LJG. 


\section{References}

Abbott, R. J., and Brochmann, C. 2003. History and evolution of the Arctic flora: in the footsteps of Eric Hultén. Molecular Ecology 12(2): 299-313.

Aiken, S.G., Dallwitz, M.J., Consaul, L.L., McJannet, C.L., Boles, R.L., Argus, G.W., Gillett, J.M., Scott, P.J., Elven, R., LeBlanc, M.C., Gillespie, L.J., Brysting, A.K., Solstad, H., and Harris, J.G. 2007. Flora of the Canadian Arctic Archipelago: Descriptions, Illustrations, Identification, and Information Retrieval [CDROM]. NRC Research Press. National Research Council of Canada. Ottawa, Ontario, Canada.

Alexander, P.J., Rajanikanth, G., Bacon, C.D., and Bailey, C.D. 2007. Recovery of plant DNA using a reciprocating saw and silica-based columns. Molecular Ecology Notes 7(1): 5-9.

Bennett, J.R., and Mathews, S. 2006. Phylogeny of the parasitic plant family Orobanchaceae inferred from phytochrome A. American Journal of Botany 93(7): 1039-1051.

Bliss, L.C. 1971. Arctic and alpine plant life cycles. Annual Review of Ecology and Systematics 2: 405-438.

Böcher, T.W., Holmen, K., and Jakobsen, K. 1968. The Flora of Greenland. P. Haase \& Son Publishers. Copenhagen, Denmark.

Brochmann, C., and Brysting, A.K. 2008. The Arctic - an evolutionary freezer? Plant Ecology \& Diversity (1)2: 181-195. doi: 10.1080/17550870802331904

Brochmann, C., Brysting, A.K., Alsos, I.G., Borgen, L., Grundt, H.H., Scheen, A.-C., and Elven, R. 2004. Polyploidy in arctic plants. Biological Journal of the Linnean Society 82: 521-536.

Cayouette, J. 2004. A taxonomic review of the Eriophorum russeolum - E. scheuchzeri complex (Cyperaceae) in North America. Sida 21: 791-814.

Chiang, T.Y., Schaal, B.A., and Peng, C.I. 1998. Universal primers for amplification and sequencing a noncoding spacer between the $a t p B$ and $r b c L$ genes of chloroplast DNA. Botanical Bulletin of Academia Sinica 39: 245-250.

Cody, W.J. 2000. Flora of the Yukon Territory, $2^{\text {nd }}$ Edition. 669 pp. NRC Research Press. National Research Council of Canada. Ottawa, Ontario, Canada.

Cortés-Burns, H., Carlson, M.L., Lipkin, R., Flagstad, L., and Yokel, D. 2009. Rare vascular plants of the North Slope. Bureau of Land Management Alaska Technical Report 58. U. S. Department of the Interior.

Ducarme, V., and Wesselingh, R.A. 2005. Detecting hybridization in mixed populations of Rhinanthus minor and Rhinanthus angustifolius. Folia Geobotanica 40(2-3): 151-161.

Eaton, D.A., and Ree, R.H. 2013. Inferring phylogeny and introgression using RADseq data: an example from flowering plants (Pedicularis: Orobanchaceae). Systematic Biology 62(5): 689-706. 
Eidesen, P.B., Carlsen, T., Molau, U., and Brochmann, C. 2007. Repeatedly out of Beringia: Cassiope tetragona embraces the Arctic. Journal of Biogeography 34: 1559-1574.

Elven R., Murray D.F., Razzhivin V.Y., and Yurtsev B.A. 2011. Annotated Checklist of the Panarctic Flora (PAF): Vascular plants, version 1.0. Available at http://www.nhm2.uio.no/paf. Accessed continuously.

Eriksen, B., Molau, U., and Svensson, M. 1993. Reproductive strategies in two Arctic Pedicularis species (Scrophulariaceae). Ecography 16(2): 154-166.

Eriksen, B., and Töpel, M.H. 2006. Molecular phylogeography and hybridization in members of the circumpolar Potentilla sect. Niveae (Rosaceae). American Journal of Botany 93(3): 460-469.

Fazekas A.J., Burgess K.S., Kesanakurti P.R., Graham S.W., Newmaster S.G., Husband, B.C., Percy, D.M., Hajibabaei, M., and Barrett, S.C.H. 2008. Multiple multilocus DNA barcodes from the plastid genome discriminate plant species equally well. PLoS ONE 3(7): e2802. doi: 10.1371/journal.pone.0002802

Fedorov, V.B., and Stenseth, N.C. 2002. Multiple glacial refugia in the North American Arctic: inference from phylogeography of the collared lemming (Dicrostonyx groenlandicus). Proceedings of the Royal Society of London 269: 2071-2077. doi: 10.1098/rspb.2002.2126

Gillespie, L.J. and Boles, R.. 2001. Phylogenetic relationships and infraspecific variation in Canadian Arctic Poa based on chloroplast DNA restriction site data. Canadian Journal of Botany 79: 679-701. doi: 10.1139/cjb-79-5-679.

Gillespie, L.J., Consaul, L.L., and Aiken, S.G. 1997. Hybridization and the origin of the arctic grass Poa hartzii (Poaceae): evidence from morphology and chloroplast DNA restriction site data. Canadian Journal of Botany 75(11): 1978-1997. doi: 10.1139/b97-910.

Guldahl, A. S., Borgen, L., and Nordal, I. 2001. Variation in the Festuca brachyphylla (Poaceae) complex in Svalbard, elucidated by chromosome numbers and isozymes. Botanical Journal of the Linnean Society 137(2): 107-126.

Hammer, Ø., Harper, D., and Ryan, P. 2001. PAST: Paleontological Statistics Software Package for Education and Data Analysis. Palaeontologia Electronica 4(1): 1-9.

Harrison, R.G., and Larson, E.L. 2014. Hybridization, introgression, and the nature of species boundaries. Journal of Heredity 105(S1): 795-809. doi: 10.1093/jhered/esu033

Hedberg, O. 1967. Chromosome numbers of vascular plants from arctic and sub-arctic North America. Arkiv fur Botanik, series 2, 6: 309-326.

Hegi, G. 1909. Illustrierte Flora van Mittel-Europa. Bd. VI 2. Carl Hanser, München, Germany. Hultén, E. 1964. The Circumpolar Plants. Almqvist \& Wiksell. Stockholm, Sweden. 
Hultén, E. 1968. Flora of Alaska and Neighboring Territories: a Manual of the Vascular Plants. Stanford University Press. Stanford, California, U.S.A.

Kress, W.J., and Erickson, D.L. 2007. A two-locus global DNA barcode for land plants: the coding $r b c L$ gene complements the non-coding trnH-psbA spacer region. PLoS ONE 2(6): e508. doi:10.1371/journal.pone.0000508

Léveillé-Bourret, É., Bailleul, S.M., Cayouette, J., and Joly, S. 2014. Testing hybridization hypotheses with morphometry : the case of Eastern American species of Potentilla sect. Niveae (Rosaceae). Systematic Botany 39(1): 193-204.

Levin, R.A., Wagner, W.L., Hoch, P.C., Nepokroeff, M., Chris Pires, J., Zimmer, E.A., and Sytsma, K.J. 2003. Family-level relationships of Onagraceae based on chloroplast $r b c L$ and $n d h F$ data. American Journal of Botany 90(1): 107-115.

Li, H.-L. 1948. A revision of the genus Pedicularis in China. Part I. Proceedings of the Academy of Natural Sciences of Philadelphia 100: 205-378.

Li, H.-L. 1951. Evolution in the flowers of Pedicularis. Evolution 5(2): 158-164.

Macior, L.W. 1975. The pollination ecology of Pedicularis (Scrophulariaceae) in the Yukon Territory. American Journal of Botany 62: 1065-1072.

Macior, L.W. 1983. The pollination dynamics of sympatric species of Pedicularis (Scrophulariaceae). American Journal of Botany 70: 844-853.

Mill, R. 2011. Revision of Pedicularis series Tenuirostres (Orobanchaceae). Edinburgh Journal of Botany 68(1): 61-109.

Nylander, J. 2004. MrModeltest version 2. Department of Systematic Zoology. Evolutionary Biology Centre, Uppsala University. Uppsala, Sweden.

Pennell, F.W. 1935. Pedicularis. In The Scrophulariaceae of Eastern Temperate North America. Academy of Natural Sciences of Philadelphia. Philadelphia, Pennsylvania, U.S.A.

Philipp, M. 1998. Genetic variation in four species of Pedicularis (Scrophulariaceae) within a limited area in west Greenland. Arctic and Alpine Research 30(4): 396-399.

Philipp, M., Woodell, S. R. J., Böcher, J., and Mattsson, O. 1996. Reproductive biology of four species of Pedicularis (Scrophulariaceae) in West Greenland. Arctic and Alpine Research 28(4): 403-413.

Polunin, N. 1940. Botany of the Canadian Eastern Arctic. Part. 1. Pteridophyta and Spermatophyta. National Museum of Canada Bulletin 92, Biological Series 24. 408 pp. Ottawa, Ontario, Canada.

Porsild, A.E. 1955. The Vascular Plants of the Western Canadian Arctic Archipelago. National Museum of Canada Bulletin 135, Biological Series 45. 226 pp. Ottawa, Ontario, Canada. 
Porsild, A.E. 1957. Illustrated Flora of the Canadian Arctic Archipelago. National Museum of Canada Bulletin 146, Biological Series 50. 209 pp. Ottawa, Ontario, Canada.Porsild, A.E., and Cody, W.J. 1980. Vascular Plants of the Continental Northwest Territories. 667 pp. National Museum of Natural Sciences, National Museums of Canada. Ottawa, Ontario, Canada.

Rieseberg, L.H., and Brunsfeld, S.J. 1992. Molecular evidence and plant introgression. In Molecular Systematics of Plants. Springer. pp. 151-176. New York, New York, U.S.A.

Robart, B. W., Gladys, C., Frank, T., and Kilpatrick, S. 2015. Phylogeny and Biogeography of North American and Asian Pedicularis (Orobanchaceae).Systematic Botany 40(1): 229-258. doi: http://dx.doi.org/10.1600/036364415X686549.

Robart, B.W., Rahul, G., and Policicchio, B. 2011. Phylogeny and geography of Pedicularis (Orobanchaceae) in North America [Abstract]. Botany 2011, July 9-13, St. Louis, Missouri, U.S.A.

Robart, B.W. 2005. Morphological diversification and taxonomy among the varieties of Pedicularis bracteosa Benth. (Orobanchaceae). Systematic Botany 30(3): 644-656.

Ronquist, F., Teslenko, M., van der Mark, P., Ayres, D.L., Darling, A., Höhna, S., Larget, B., Liu, L., Suchard, M.A., and Huelsenbeck, J.P. 2012. MrBayes 3.2: efficient Bayesian phylogenetic inference and model choice across a large model space. Systematic Biology 61(3): 539-542.

Saarela, J.M., Sokoloff, P.C., Gillespie, L.J., Consaul, L.L., and Bull, R.D. 2013. DNA barcoding the Canadian Arctic flora: core plastid barcodes ( $r b c L+m a t K)$ for 490 vascular plant species. PLoS ONE 8(10): e77982. doi:10.1371/journal.pone.0077982

Savile, D.B.O. 1964. General ecology and vascular plants of the Hazen Camp area. Arctic 17(4): 237-258.

Savile, D.B.O. 1977. Leaf form and evolutionary patterns in Pedicularis. Proceedings of the Indian National Science Academy, Pt. B, 43: 223-227.

Shaw, J., Lickey, E.B., Beck, J.T., Farmer, S.B., Liu, W., Miller, J., Siripun, K.C., Winder, C.T., Schilling, E.E., and Small, R.L. 2005. The tortoise and the hare II: relative utility of 21 noncoding chloroplast DNA sequences for phylogenetic analysis. American Journal of Botany 92(1): 142-166.

Simmons, H.G. 1906. The Vascular Plants in the Flora of Ellesmereland. Report of the $2^{\text {nd }}$ Norwegian Arctic Expedition in the "Fram", 1898-1902, No. 2. The Society of Arts and Sciences of Kristiania, Kristiania, Norway.

Sokoloff, P.C., and Gillespie, L.J. 2012. Taxonomy of Astragalus robbinsii var. fernaldii (Fabaceae): molecular and morphological analyses support transfer to Astragalus eucosmus. Botany 90(1): 11-26. doi: 10.1139/b11-077.

Solstad, H. 2008. Taxonomy and evolution of the diploid and polyploid Papaver sect. Meconella (Papaveraceae). Philosophiae doctor dissertation. Faculty of Mathematics and Natural Sciences, National Centre for Biosystematics, Natural History Museum, University of Oslo. Oslo, Norway. 237 pp. 
Soltis, D.E., Soltis, P.S., and Milligan, B.G. 1992. Intraspecific chloroplast DNA variation: systematic and phylogenetic implications. In Molecular Systematics of Plants. Springer. pp. 117-150. New York, New York, U.S.A.

Soper, J. H., and Powell, J. M. 1985. Botanical studies in the Lake Hazen Region, northern Ellesmere Island, Northwest Territories, Canada. Publications in Natural Sciences, No. 5.67 pp. National Museum of Natural Sciences, Ottawa, Ontario, Canada.

Steen, N. W., Elven, R., and Nordal, I. 2004. Hybrid origin of the arctic $\times$ Pucciphippsia vacillans (Poaceae): evidence from Svalbard plants. Plant Systematics and Evolution 245(3-4): 215-238.

Swales, D.E. 1979. Nectaries of certain arctic and sub-arctic plants with notes on pollination. Rhodora 81: 363-407.

Swofford, D.L. 2003. PAUP*: phylogenetic analysis using parsimony (*and other methods), version 4. Sinauer, Sunderland, Massachusetts, U.S.A.

Taberlet, P., Gielly, L., Pautou, G., and Bouvet, J. 1991. Universal primers for amplification of three noncoding regions of chloroplast DNA. Plant Molecular Biology 17(5): 1105-1109.

Tkach, N., Ree. R.H., Kuss, P., Röser, M., and Hoffmann, M.H. 2014. High mountain origin, phylogenetics, evolution, and niche conversatism of arctic lineages in the hemiparisitic genus Pedicularis (Orobanchaceae). Molecular Phylogenetics and Evolution 76: 75-92. doi: 10.1016/j.ympev.2014.03.004

Tremblay, N.O., and Schoen, D.J. 1999. Molecular phylogeography of Dryas integrifolia: glacial refugia and postglacial recolonization. Molecular Ecology 8: 1189-1198.

Welsh, S.L. 1974. Anderson's Flora of Alaska and Adjacent Parts of Canada. Brigham Young University Press 724pp. Provo, Utah, U.S.A.

Williams, J.B., and Batzli, G.O. 1982. Pollination and dispersion of five species of lousewort (Pedicularis) near Atkasook, Alaska, U.S.A. Arctic and Alpine Research 14(1): 59-73. http://doi.org/10.2307/1550816

White, T.J., Bruns, T., Lee, S., and Taylor, J. 1990. Amplification and direct sequencing of fungal ribosomal RNA genes for phylogenetics. PCR protocols: a guide to methods and applications 18: 315322.

Wolfe, A.D., Randle, C.P., Liu, L., and Steiner, K.E. 2005. Phylogeny and biogeography of Orobanchaceae. Folia Geobotanica 40 (2-3): 115-134.

Yang, F.S., and Wang, X.Q. 2007. Extensive length variation in the cpDNA trnT-trnF region of hemiparasitic Pedicularis and its phylogenetic implications. Plant Systematics and Evolution 264(3-4): 251-264.

Zhukova, P.G. 1966. Chromosome numbers in some species of plants of the north-eastern part of USSR. Botanicheskii Zhurnal. Moscow \& Leningrad 51: 1511-1516. 
Table

Table 1. Morphological characters measured for Pedicularis hirsuta and $P$. langsdorffii subsp. arctica, the number of specimens measured in each taxon per variable, the median and standard deviation, and the Mann-Whitney $\mathrm{U}$ and $\mathrm{Z}$ statistics, as well as the $p$ value from the MannWhitney $\mathrm{U}$ pairwise comparisons. Measurements of putative hybrid specimens are given separately; for the Truelove site median values and standard deviations based on four specimens are given.

\begin{tabular}{|c|c|c|c|c|c|c|c|c|c|c|c|c|c|c|}
\hline $\begin{array}{l}\text { Continuous quantitative } \\
\text { variables measured (mm) }\end{array}$ & $\begin{array}{c}\mathrm{n}-\mathrm{P} \\
\text { hirsuta }\end{array}$ & $\begin{array}{l}\text { Median - } \\
\text { P. hirsuta }\end{array}$ & $\begin{array}{l}\text { SD - P. } \\
\text { hirsuta }\end{array}$ & $\begin{array}{l}\mathrm{n}-P . \mathrm{l} . \\
\text { arctica }\end{array}$ & $\begin{array}{c}\text { Median - } \\
\text { P. I. } \\
\text { arctica }\end{array}$ & $\begin{array}{c}\text { SD - P. I. } \\
\text { arctica }\end{array}$ & $\begin{array}{c}\text { Mann- } \\
\text { Whitney } \\
\text { U }\end{array}$ & $\mathbf{Z}$ & $p$ value & $\begin{array}{l}\text { Median - } \\
\text { Truelove }\end{array}$ & $\begin{array}{c}\text { SD - } \\
\text { Truelove }\end{array}$ & $\begin{array}{c}\text { Gillespie } \\
6478\end{array}$ & $\begin{array}{c}\text { Gillespie } \\
6138\end{array}$ & $\begin{array}{l}\text { Parker } \\
\text { 73061a }\end{array}$ \\
\hline A. Inflorescence length & 50 & 37.1 & 22.90 & 53 & 66.0 & 30.31 & 609 & -4.7214 & $2.34 \mathrm{E}-06$ & 23.9 & 8.41006 & 25.1 & 42.1 & 19.2 \\
\hline B. Calyx long sepal length & 50 & 7.2 & 1.14 & 53 & 8.3 & 1.33 & 670.5 & -4.3166 & $1.58 \mathrm{E}-05$ & 7.2 & 1.75404 & 6.2 & 7.3 & 6.2 \\
\hline C. Calyx short sepal length & 50 & 5.9 & 1.28 & 53 & 6.5 & 1.43 & 1039.5 & -1.8814 & 5.99E-02 & 5.25 & 1.23962 & 4.8 & 3.6 & 5.5 \\
\hline D. Calyx width & 50 & 3.2 & 0.52 & 53 & 3.8 & 0.66 & 782 & -3.5827 & $3.40 \mathrm{E}-04$ & 3.55 & 0.55678 & 3.5 & 3.2 & 4.0 \\
\hline E. Corolla length & 50 & 13.7 & 2.28 & 53 & 20.8 & 2.90 & 127 & -7.9021 & $2.74 \mathrm{E}-15$ & 14.8 & 2.69815 & 19.2 & 15.4 & 18.7 \\
\hline F. Corolla lip width & 48 & 6.2 & 1.41 & 51 & 10.3 & 3.09 & 241 & -6.8796 & $6.00 \mathrm{E}-12$ & 9.6 & 2.49533 & 7.0 & 5.3 & 6.5 \\
\hline G. Galea width & 50 & 2.1 & 0.44 & 53 & 3.3 & 0.46 & 81 & -8.2082 & $2.25 \mathrm{E}-16$ & 2.65 & 0.21602 & 2.9 & 3.2 & 3.8 \\
\hline H. Style protruberance & 50 & 0 & 0 & 53 & 1.1 & 0.58 & 0 & -9.2896 & $1.55 \mathrm{E}-20$ & 1.15 & 0.57951 & 1.1 & 0.6 & 0.7 \\
\hline I. Anther length & 50 & 1.5 & 0.23 & 51 & 2.4 & 0.28 & 1 & -8.6651 & $4.51 \mathrm{E}-18$ & 2.05 & 0.14142 & 2.3 & 2.6 & 2.2 \\
\hline J. Galea teeth distance to tip & 49 & 0.4 & 0.25 & 53 & 1.0 & 0.29 & 224.5 & -7.2025 & $5.91 \mathrm{E}-13$ & 0.6 & 0.2708 & 0.7 & 1.0 & 0.4 \\
\hline K. Galea teeth length & 50 & 0.1 & 0.11 & 53 & 0.4 & 0.17 & 216 & -7.405 & $1.31 \mathrm{E}-13$ & 0.3 & 0 & 0.1 & 0.2 & 0.1 \\
\hline L. Galea teeth width & 49 & 015 & 0.08 & 53 & 0.2 & 0.07 & 905 & -2.6976 & $6.98 \mathrm{E}-03$ & 0.15 & 0.05774 & 0.2 & 0.1 & 0.1 \\
\hline M. Stem length & 50 & 111.5 & 37.38 & 53 & 128.0 & 40.72 & 1071.5 & -1.6696 & $9.50 \mathrm{E}-02$ & 51.4 & 15.337 & 71.5 & 150.0 & 71.1 \\
\hline N. Stem width & 50 & 2.6 & 0.68 & 53 & 3.1 & 0.93 & 926.5 & -2.6969 & $8.62 \mathrm{E}-02$ & 1.9 & 0.37749 & 2.0 & 3.2 & 2.7 \\
\hline O. Cauline leaf blade length & 50 & 15.8 & 4.87 & 52 & 17.3 & 6.14 & 1220 & -0.53 & 5.94E-01 & 7.35 & 1.14419 & 14.8 & 11.3 & 11.6 \\
\hline P. Cauline leaf blade width & 50 & 4.4 & 1.13 & 52 & 3.6 & 1.25 & 944.5 & -2.376 & 1.70E-02 & 2.4 & 0.54467 & 4.5 & 4.3 & 2.1 \\
\hline Q. Cauline leaf petiole length & 50 & 11.5 & 3.07 & 52 & 12.2 & 4.25 & 1157.5 & -0.95 & $3.40 \mathrm{E}-01$ & 7.6 & 1.7519 & 12.0 & 10.0 & 12.5 \\
\hline R. Cauline leaf petiole width & 50 & 2.5 & 0.73 & 52 & 1.2 & 0.90 & 1116 & -1.2287 & $2.19 \mathrm{E}-01$ & 1.9 & 0.6377 & 1.2 & 4.3 & 1.9 \\
\hline S. Cauline leaf lobe length & 50 & 1.5 & 0.53 & 52 & 1.3 & 0.56 & 934 & -2.449 & $1.43 \mathrm{E}-02$ & 0.95 & 0.09574 & 1.4 & 1.2 & 0.8 \\
\hline T. Cauline leaf lobe width & 50 & 1.1 & 0.36 & 52 & 0.9 & 0.34 & 932.5 & -2.462 & $1.38 \mathrm{E}-02$ & 0.5 & 0.17321 & 0.9 & 0.9 & 1.3 \\
\hline U. Bract blade length & 50 & 9.3 & 3.52 & 51 & 10.7 & 5.35 & 1100 & -1.1853 & $2.36 \mathrm{E}-01$ & 6.1 & 1.97922 & 4.3 & 4.9 & 6.4 \\
\hline V. Bract blade width & 50 & 3.3 & 0.92 & 51 & 2.8 & 0.94 & 919.5 & -2.41 & $1.58 \mathrm{E}-02$ & 2.35 & 0.9815 & 2.0 & 2.5 & 2.3 \\
\hline W. Bract petiole length & 50 & 7.2 & 2.17 & 50 & 8.6 & 3.18 & 849.5 & -2.75 & $5.80 \mathrm{E}-03$ & 6.25 & 1.84572 & 5.8 & 4.6 & 8.0 \\
\hline X. Bract petiole width & 50 & 2.9 & 0.94 & 51 & 2.5 & 1.24 & 993.5 & -1.909 & $5.26 \mathrm{E}-02$ & 2.25 & 0.86735 & 2.1 & 3.5 & 3.0 \\
\hline Y. Bract lobe length & 49 & 1.2 & 0.36 & 50 & 1.1 & 0.48 & 947.5 & -1.9431 & $5.20 \mathrm{E}-02$ & 1.05 & 0.38622 & 0.6 & 1.1 & 0.8 \\
\hline Z. Bract lobe width & 50 & 0.9 & 0.25 & 50 & 0.8 & 0.31 & 1206 & -0.301 & 7.63E-01 & 0.55 & 0.3594 & 0.7 & 0.8 & 1.1 \\
\hline \multicolumn{15}{|c|}{ Qualitative characters measured } \\
\hline \multicolumn{15}{|c|}{ AA. Stem hair density (0-glabrous, 1-glabrate, 2-sparse, 3- moderate, 4- dense, 5-very dense) } \\
\hline \multicolumn{15}{|c|}{ BB. Inflorescence hair density (0-glabrous, 1-glabrate, 2-sparse, 3- moderate, 4- dense, 5-very dense) } \\
\hline
\end{tabular}




\section{Figure Captions}

Figure 1: Distribution of Pedicularis hirsuta and Pedicularis langsdorffii subsp. arctica in Canada based on National Herbarium of Canada (CAN) specimen data (top), and map of specimens sampled for DNA based on cpDNA genotype (bottom). Map created using SimpleMappr (Shorthouse 2010) using data in the Public Domain.

Figure 2: Pedicularis hirsuta, A. habit, B. inflorescence, C. flower showing galea with no teeth and nonprotruding, strongly recurved style (Sokoloff 332a, CAN). Photos by P.C. Sokoloff.

Figure 3: Pedicularis langsdorffii subsp. arctica, A. habit, B. inflorescence, C. flower showing galea with teeth and protruding style (Saarela et al. 3618, CAN). Photos by P.C. Sokoloff.

Figure 4: Illustration of Pedicularis langsdorffii subsp. arctica flower showing ten morphological measurements performed on each specimen examined. Illustration by C.J. Chapman.

Figure 5: Bayesian phylogram of 82 ITS sequences of Pedicularis hirsuta, $P$. langsdorffii subsp. arctica, $P$. lanata, $P$. albolabiata and $P$. labradorica. Posterior probability scores are indicated above each branch, maximum parsimony bootstrap values are located below. Maximum parsimony tree consistency index (Cl): 0.94 .

Figure 6: Strict consensus of 24 most parsimonious trees generated from 78 atpl-atpH sequences of Pedicularis hirsuta, P. langsdorffii subsp. arctica, P. lanata, P. albolabiata and P. labradorica. Bayesian posterior probability scores are indicated above each branch, bootstrap values are located below. Maximum parsimony tree consistency index $(\mathrm{Cl})$ : 0.93.

Figure 7: Principal components analysis of 50 Pedicularis hirsuta, 53 P. langsdorffii subsp. arctica (including nine introgressed), and seven putative hybrid specimens measured for 12 continuous floral morphology characters. Four putative hybrid specimens from Truelove Inlet, Devon Island (green polygon), three hybrid specimens from other localities (Gillespie 6138. Gillespie 6478, and Parker 73061A), and one introgressed P. langsdorffii subsp. arctica from Truelove Inlet (Kerik 40) are indicated.

Figure 8: Boxplots displaying median, interquartile ranges, and minimum/maximum values for interspecific differences for 12 continuous floral morphology characters measured in Pedicularis hirsuta (blue) and $P$. langsdorffii subsp. arctica (orange). Asterisks indicate statistical significance according to a Mann-Whitney U pairwise comparison: * $p<0.001$.

Figure 9: Stacked column charts showing percent of specimens of $P$. hirsuta (50 specimens measured) and $P$. langsdorffii subsp. arctica (53 specimens measured) displaying each of six character states for two qualitative pubescence characters: A) inflorescence pubescence, B) stem pubescence. 


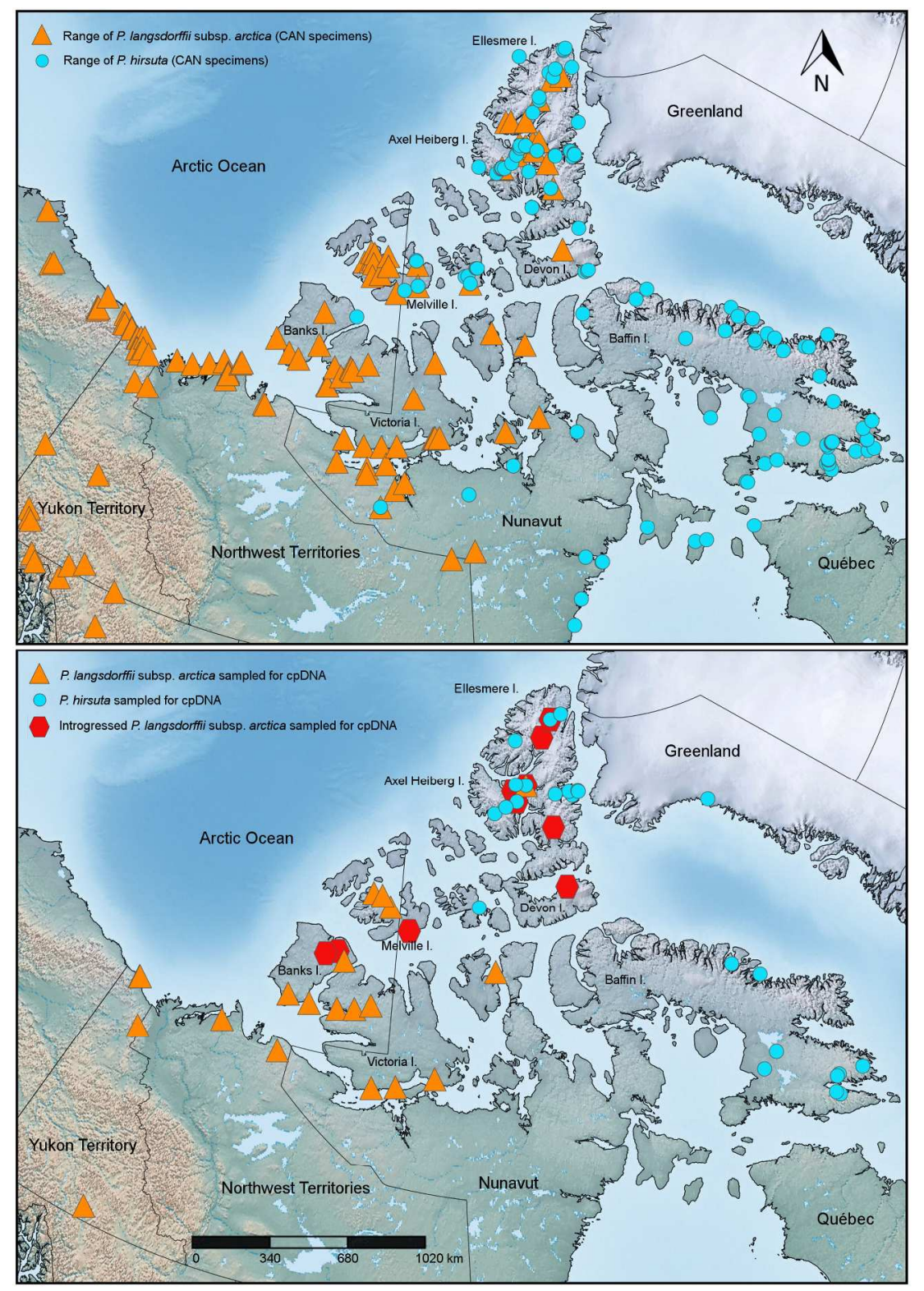

Figure 1: Distribution of Pedicularis hirsuta and Pedicularis langsdorffii subsp. arctica in Canada based on National Herbarium of Canada (CAN) specimen data (top), and map of specimens sampled for DNA based on cpDNA genotype (bottom). Map created using SimpleMappr (Shorthouse 2010) using data in the Public Domain. $182 \times 260 \mathrm{~mm}(300 \times 300 \mathrm{DPI})$ 


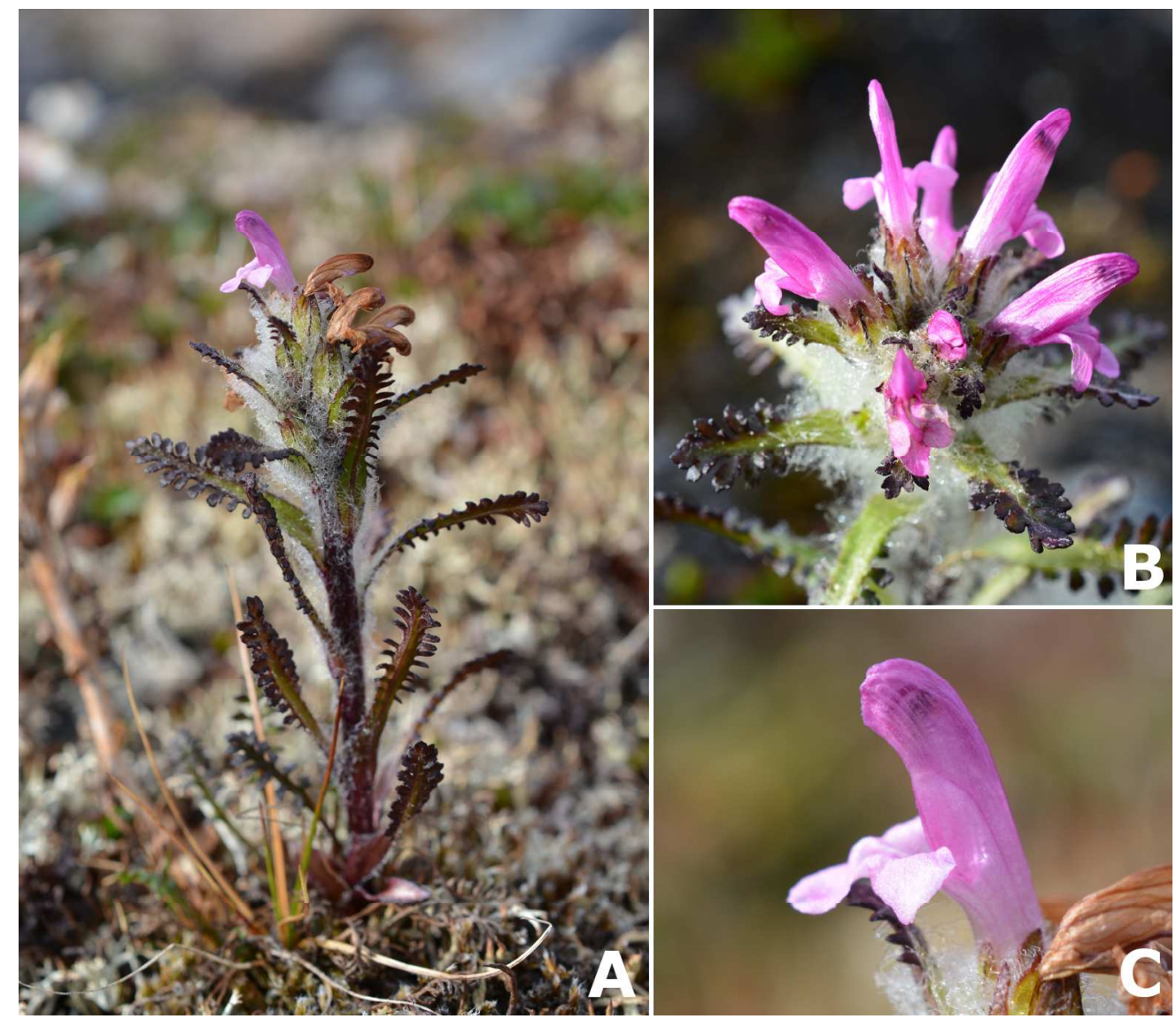

Figure 2: Pedicularis hirsuta, A. habit, B. inflorescence, C. Flower showing galea with no teeth and nonprotruding, strongly recurved style (Sokoloff 332a, CAN). Photos by P.C. Sokoloff. $169 \times 148 \mathrm{~mm}(300 \times 300 \mathrm{DPI})$ 


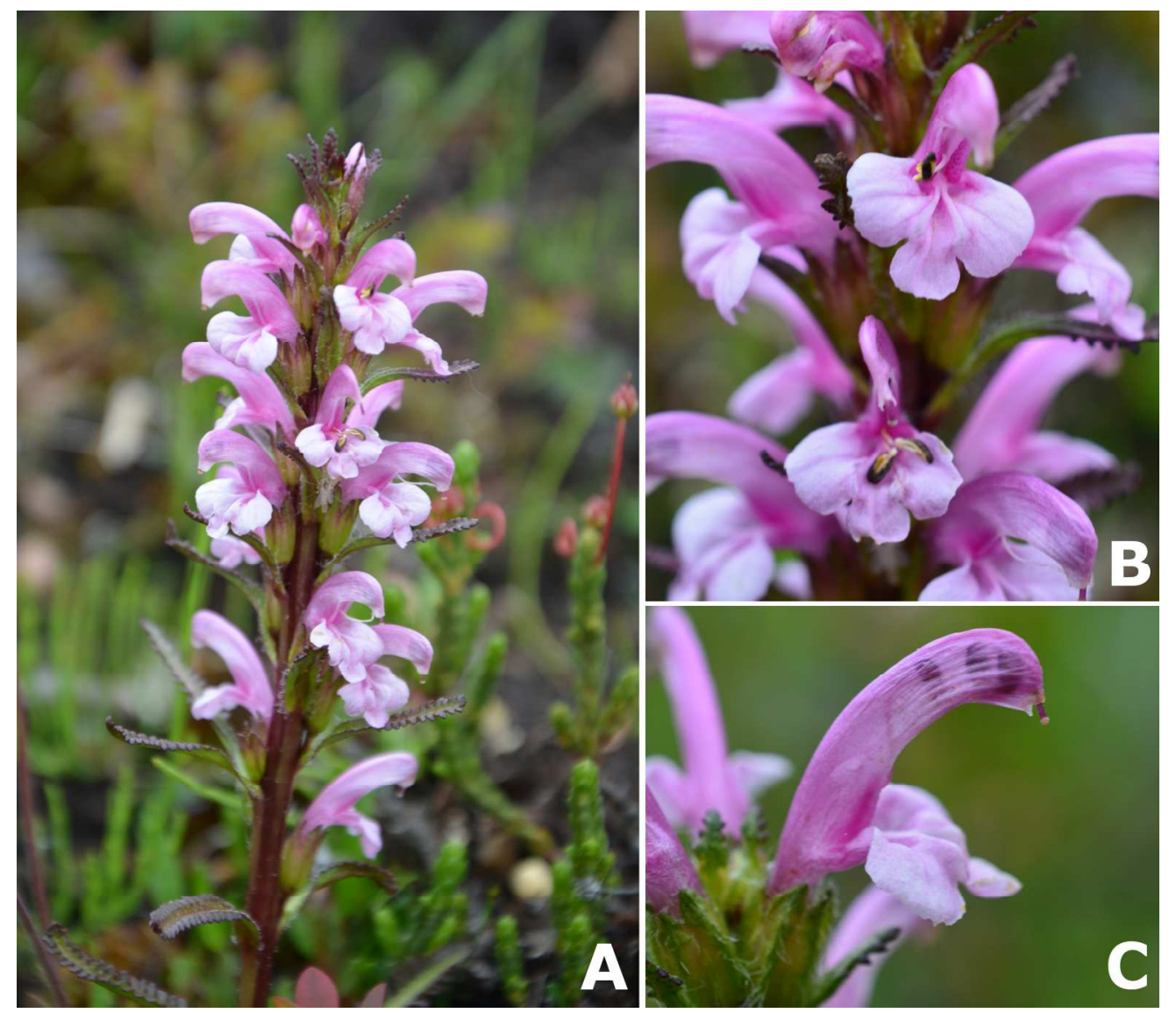

Figure 3: Pedicularis langsdorffii subsp. arctica, A. habit, B. inflorescence, C. Flower showing galea with teeth and protruding style (Saarela et al. 3618, CAN). Photos by P.C. Sokoloff. $169 \times 148 \mathrm{~mm}(300 \times 300 \mathrm{DPI})$ 


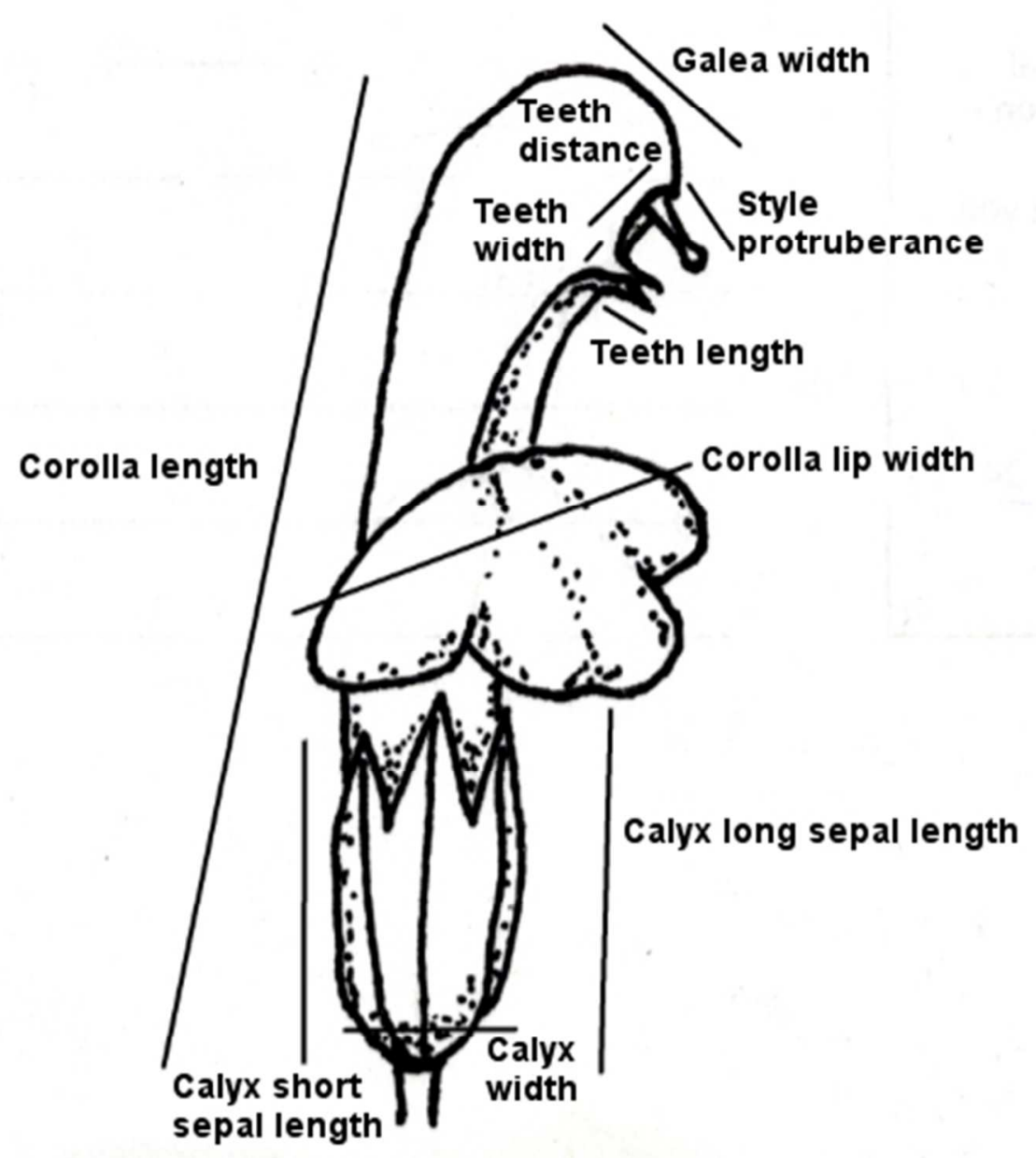

Figure 4: Illustration of Pedicularis langsdorffii subsp. arctica flower showing ten morphological measurements performed on each specimen examined. Illustration by C.C. Chapman. $39 \times 41 \mathrm{~mm}(300 \times 300$ DPI $)$ 


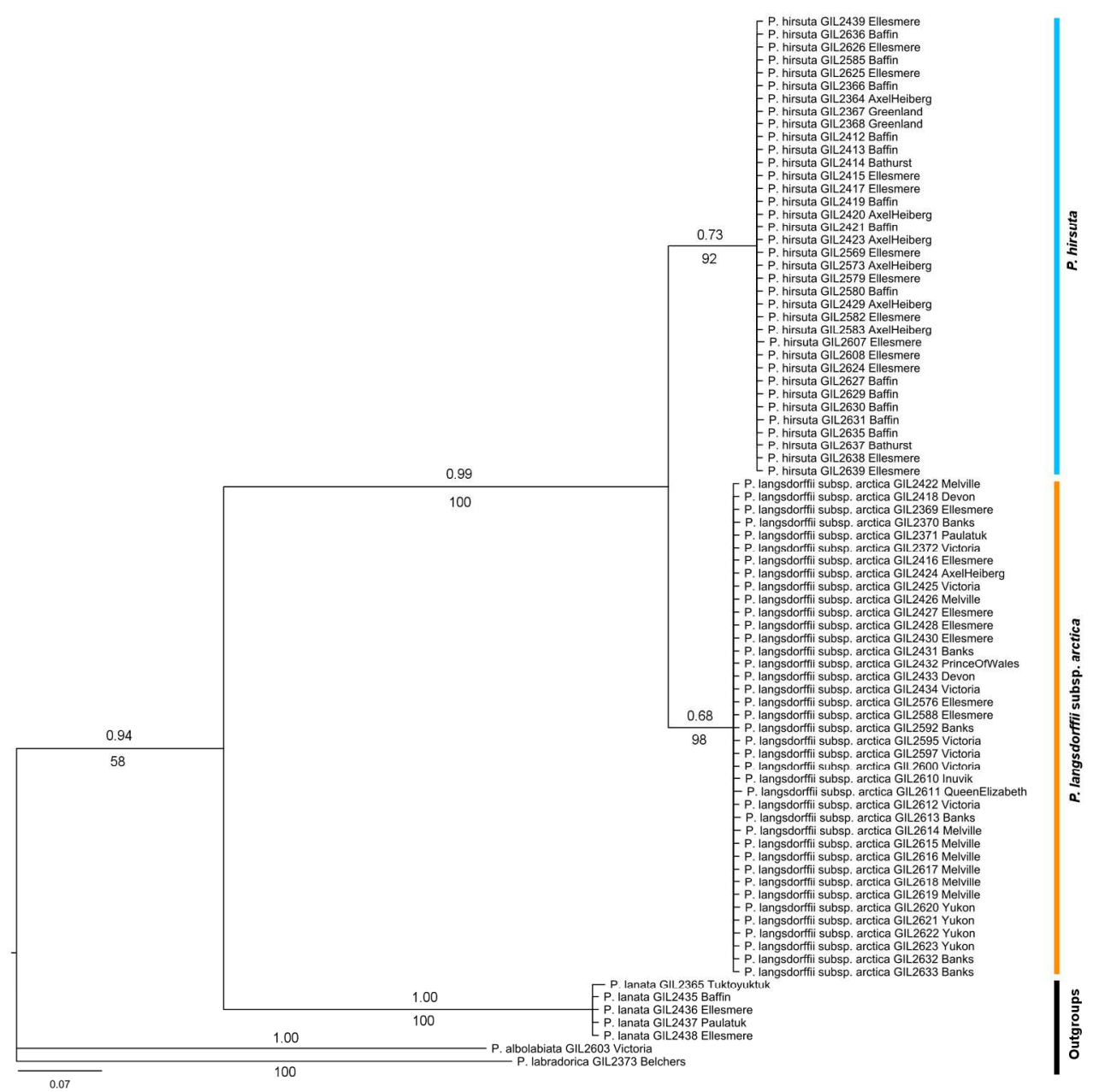

Figure 5: Bayesian phylogram of 82 ITS sequences of Pedicularis hirsuta, P. langsdorffii subsp. arctica, P. lanata, P. albolabiata and P. labradorica. Posterior probability scores are indicated above each branch, maximum parsimony bootstrap values are located below. Consistency Index (CI): 0.94 . $177 \times 173 \mathrm{~mm}(300 \times 300 \mathrm{DPI})$ 


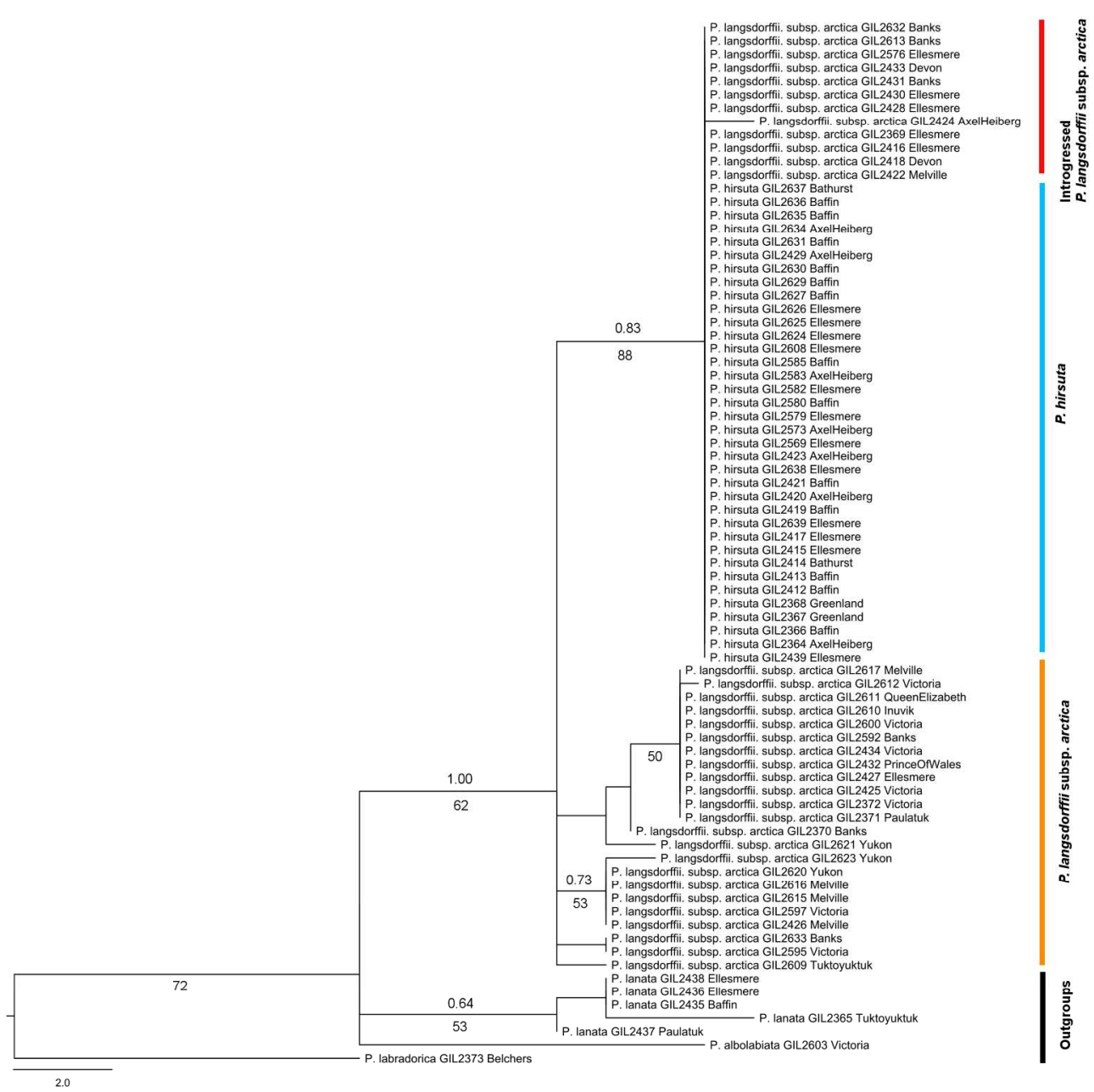

Figure 6: Strict consensus of 24 most parsimonious trees generated from 78 atpI-atpH sequences of Pedicularis hirsuta, P. langsdorffii subsp. arctica, P. lanata, P. albolabiata and P. labradorica. Bayesian posterior probability scores are indicated above each branch, bootstrap values are located below.

Consistency Index (CI): 0.93 .

$177 \times 173 \mathrm{~mm}(300 \times 300$ DPI) 


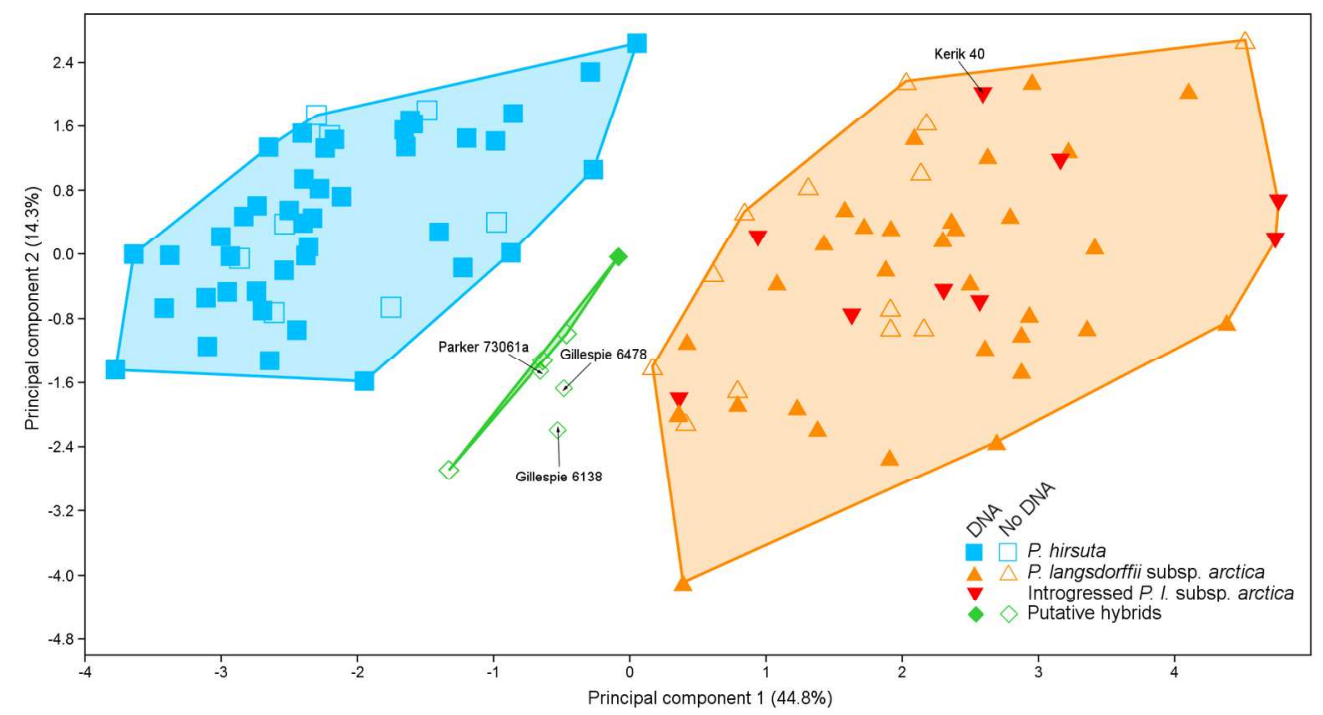

Figure 7: Principal components analysis of 50 Pedicularis hirsuta, 53 P. langsdorffii subsp. arctica (including nine introgressed), and seven putative hybrid specimens measured for 12 continuous floral morphology characters. Four putative hybrid specimens from Truelove Inlet, Devon Island (green polygon), three hybrid specimens from other localities (Gillespie 6138. Gillespie 6478, and Parker 73061A), and one introgressed P. langsdorffii subsp. arctica from Truelove Inlet (Kerik 40) are indicated.

$158 \times 87 \mathrm{~mm}(300 \times 300 \mathrm{DPI})$ 

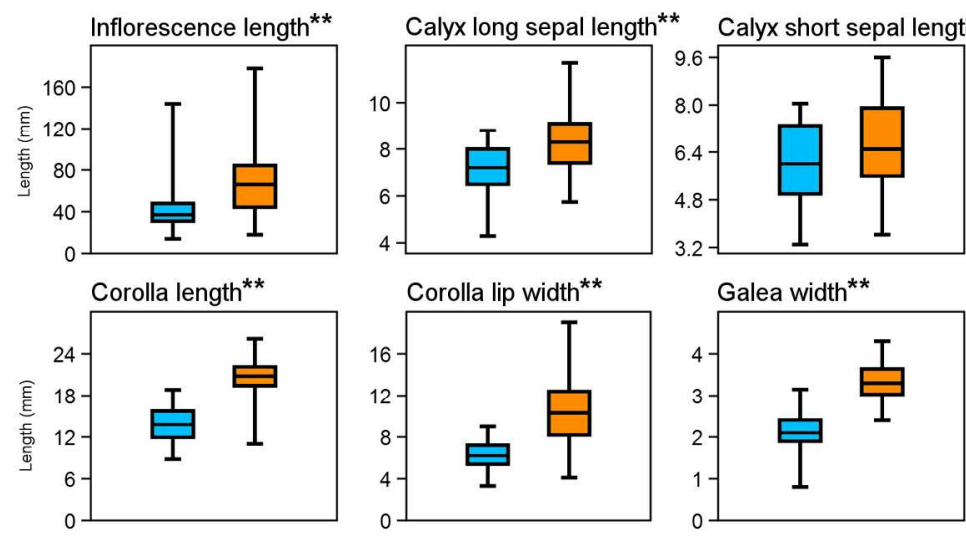

Galea width**
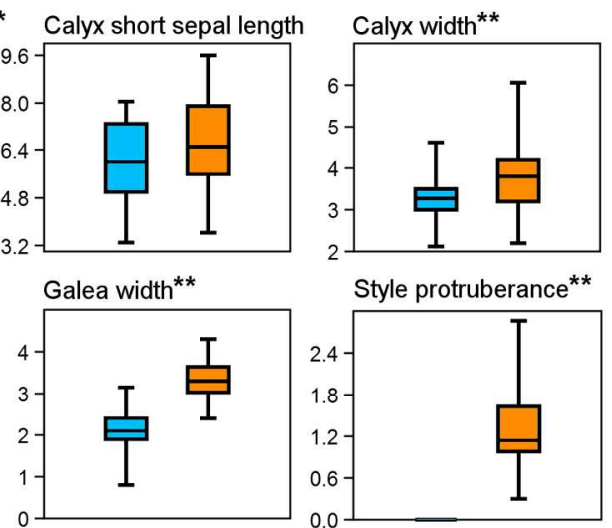

Style protruberance ${ }^{\star *}$
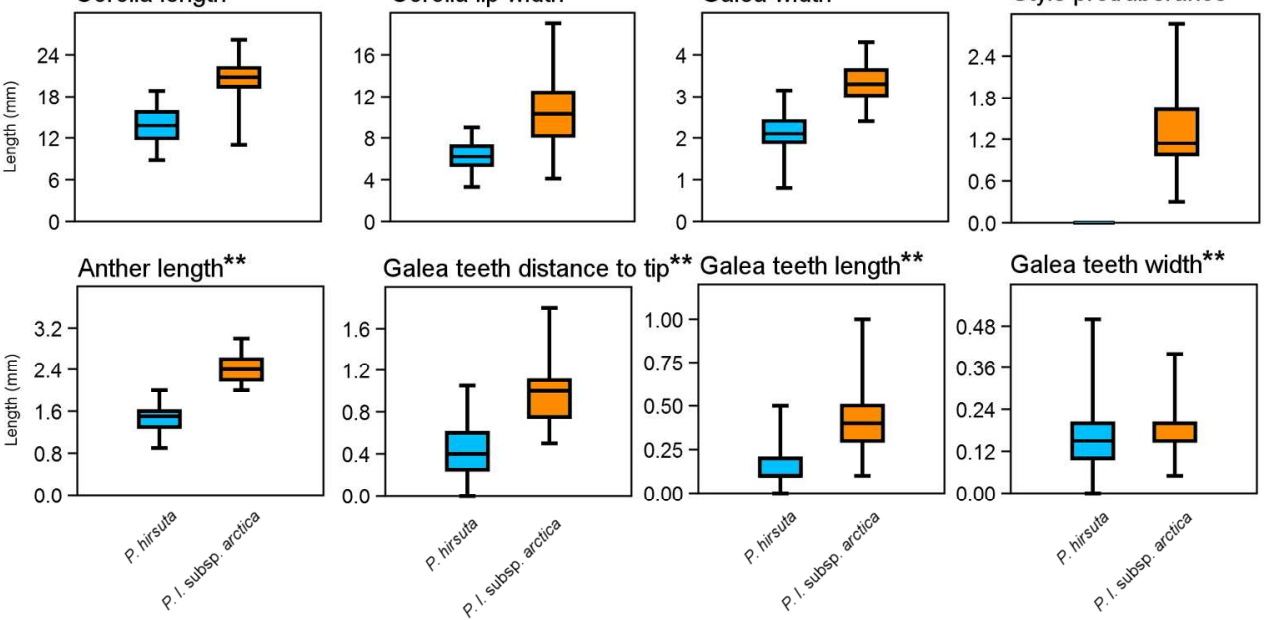

Galea teeth width**

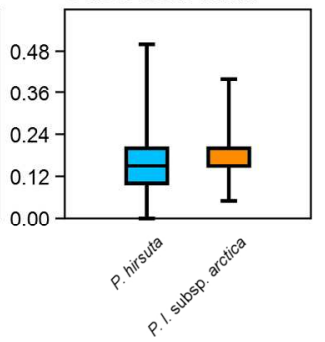

Figure 8: Boxplots displaying median, interquartile ranges, and minimum/maximum values for interspecific differences for 12 continuous floral morphology characters measured in Pedicularis hirsuta (blue) and P. langsdorffii subsp. arctica (orange). Asterisks indicate statistical significance according to a Mann-Whitney $U$ pairwise comparison: ${ }^{*} \mathrm{p}<0.05, * * \mathrm{p}<0.001$. $174 \times 125 \mathrm{~mm}(300 \times 300 \mathrm{DPI})$ 

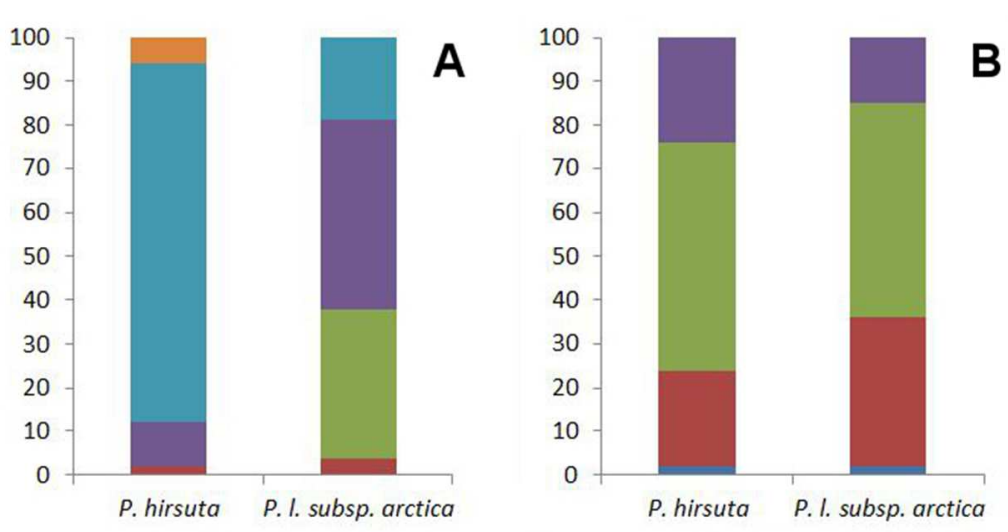

$$
\begin{aligned}
& \text { 밈 Very Dense } \\
& \text { anse } \\
& \text { noderate } \\
& \text { - Sparse } \\
& \text { alabrate } \\
& \text { n Glabrous }
\end{aligned}
$$

Figure 9: Stacked column charts showing percent of specimens of $P$. hirsuta (50 specimens measured) and P. langsdorffii subsp. arctica (53 specimens measured) displaying each of six character states for two qualitative pubescence characters: A) inflorescence pubescence, B) stem pubescence. 
Appendix A - Specimens verified for mapping, sampled for DNA sequencing, or measured for morphological analysis. Format of specimen citations is as follows: COUNTRY: PROVINCE: Locality, Collection date, Collectors and number, (Herbarium accession number), Extraction number, GenBank accession number for ITS, GenBank accession number for atpl-atpH, and a " $\mathrm{M}$ " if included in our morphology analyses, or a " $\mathrm{F}$ " if omitted from the analysis as the specimen was fruiting (only applicable to $P$. hirsuta, $P$. langsdorffii subsp. arctica, and hybrids). Missing or not applicable data is indicated with "-".

Pedicularis albolabiata: CANADA: NORTHWEST TERRITORIES: Victoria Island, Minto Inlet, $71^{\circ} 33^{\prime} \mathrm{N}$, $115^{\circ} 26^{\prime}$ W, July 24, 2010, L.J. Gillespie, J.M. Saarela, J. Doubt, R.D. Bull \& P.C. Sokoloff 10199, (CAN 599178), GIL_2603, KJ571370, KJ571288.

Pedicularis hirsuta: CANADA: NUNAVUT: Axel Heiberg Island, Diana Lake, Head of Mokka Fiord, 79³0' $\mathrm{N}$, 88 $30^{\prime}$ 'W, August 1-8, 1953, A.E. Porsild 18717, (CAN 223362), -, -, -, M; Axel Heiberg Island, Expedition Fiord, 79²4'N, 9048'W, July 18, 1996, L.J. Gillespie \& C. Vogel 6108-3, (CAN 586297), GIL_2578, -, -, M; Axel Heiberg Island, Expedition Fiord, $79^{\circ} 24^{\prime} \mathrm{N}, 90^{\circ} 48^{\prime} \mathrm{W}$, July 31, 1999, L.J. Gillespie \& L.L. Consaul 6540, (CAN 586185), GIL_2423, KJ571312, KJ571232, M; Axel Heiberg Island, Expedition Fiord, 79²4'N, $90^{\circ} 48^{\prime} W$, July 19, 1996, L.J. Gillespie \& C. Vogel 6108, (CAN 586297), GIL_2583, KJ571319, KJ571238, M; Axel Heiberg Island, Kanguk Peninsula, $79^{\circ} 16^{\prime} \mathrm{N}, 92^{\circ} 10^{\prime} \mathrm{W}$, July 5-6, 1977, G. Whalen 9, (CAN 432818), GIL_2420, KJ571310, KJ571229, M; Axel Heiberg Island, Mokka Fiord, 79²9'N, 87²2'W, July 15, 1996, L.J. Gillespie \& C. Vogel 6084, (CAN 607180), GIL_2575, -, -, M; Axel Heiberg Island, Mokka Fiord, $79^{\circ} 29^{\prime} \mathrm{N}, 87^{\circ} 22^{\prime} \mathrm{W}$, July 15, 1996, L.J. Gillespie \& C. Vogel 6094, (CAN 607184), GIL_2577, -, -, M; Axel Heiberg Island, Mokka Fiord, $79^{\circ} 29^{\prime} \mathrm{N}, 87^{\circ} 22^{\prime} \mathrm{W}$, July 16, 1996, L.J. Gillespie \& C. Vogel 6098, (-), GIL_2364, KJ571301, KJ571218, M; Axel Heiberg Island, Mokka Fiord, 79²9'N, 87²2'W, July 15, 1996, L.J. Gillespie \& C. Vogel 6077, (CAN 607181), GIL_2573, KJ571314, KJ571234, M; Axel Heiberg Island, N. Colour Lake, -, July 22-23, 1967, M. Kuc 525, (CAN 331368), GIL_2429, KJ571317, KJ571247, M; Axel Heiberg Island, Thompson Valley, -, July 24, 1960, R.E. Beschel 11065, (CAN 267752), GIL_2634, -, KJ571249, M; Axel Heiberg Island, Vicinity of Upper House, -, July 22-23, 1967, M. Kuc 542, (CAN 331377), -, -, -, M; Baffin Island, $10 \mathrm{~km}$ W of Nedlukseak Fiord, $67^{\circ} 50^{\prime} \mathrm{N}, 66^{\circ} 55^{\prime} \mathrm{W}$, July 14, 1985, $R$. Morrison 26-O, (CAN 499381), GIL_2586, -, -, F; Baffin Island, Arctic Bay, Admiralty Inlet, $73^{\circ} 13^{\prime} \mathrm{N}$, $84^{\circ} 0^{\prime} \mathrm{W}$, August 12, 1927, M.O. Malte 119164, (CAN 97642), -, -, -, F; Baffin Island, Auyuittuq National

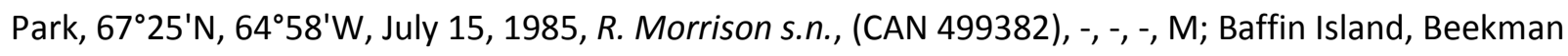
Peninsula, 632 $24^{\prime} \mathrm{N}, 64^{\circ} 40^{\prime} \mathrm{W}$, August 3, 1964, I.A. McLaren s.n., (CAN 284048), GIL_2635, KJ571327,

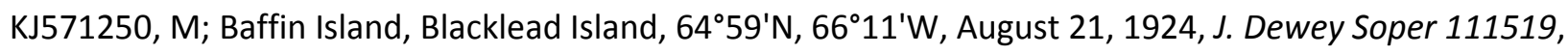
(CAN 97647), -, -, -, F; Baffin Island, Botany Bay, Kangerdluak Fiord, Nunavut Islands, 68 $50^{\prime} \mathrm{N}, 68^{\circ} 30^{\prime} \mathrm{W}$, July 20, 1967, P.J. Webber 1235, (CAN 312096), GIL_2627, KJ571323, KJ571244, M; Baffin Island,

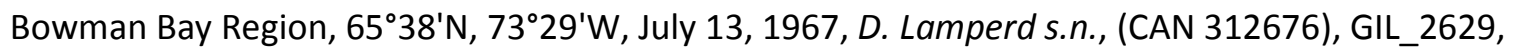
KJ571324, KJ571245, M; Baffin Island, Cape Dorset, 64¹0'N, 76²0'W, July 3, 1926, J. Dewey Soper

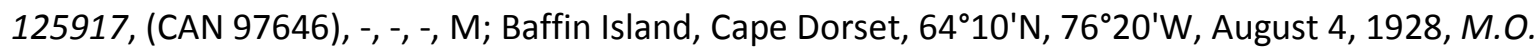
Malte 120350, (CAN 97635), -, -, -, F; Baffin Island, Clyde Inlet, 69 $50^{\prime} \mathrm{N}, 70^{\circ} 40^{\prime} \mathrm{W}$, July 3, 1950, V.C. Wynne-Edwards 8891, (CAN 204949), GIL_2628, -, -, M; Baffin Island, Clyde Inlet, 6950'N, 7040'W, June 29, 1950, V.C. Wynne-Edwards 8861, (CAN 204946), GIL_2630, KJ571325, KJ571246, M; Baffin Island, 
Frobisher, 634' $\mathrm{N}, 68^{\circ} 31^{\prime} \mathrm{W}$, July 25, 1982, J.M. Gillett 19045, (CAN 466226), GIL_2584, -, -, M; Baffin

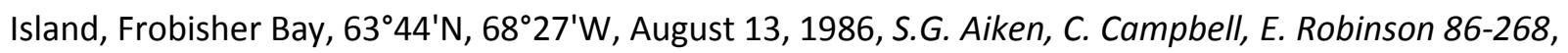
(CAN 518125), GIL_2585, KJ571298, KJ571239, M; Baffin Island, Frobisher Bay, -, July 13, 1948, C. Thacker s.n., (CAN 97628), GIL_2636, KJ571296, KJ571251, M; Baffin Island, Head of Clyde Inlet, 6950'N, $70^{\circ} 40^{\prime} W$, June 25, 1950, V.C. Wynne-Edwards 8831, (CAN 204945), GIL_2631, KJ571326, KJ571248, M; Baffin Island, Inugsuin Fjord, 70'N, 68 $30^{\prime} \mathrm{W}$, July 28, 1965, R. Hainault 3841, (CAN 302021), GIL_2419, KJ571309, KJ571228, M; Baffin Island, Iqaluit, 634ㄴ' $\mathrm{N}, 68^{\circ} 41^{\prime} \mathrm{W}$, August 5, 1996, L.J. Gillespie 6256, (-), GIL_2366, KJ571300, KJ571219, F; Baffin Island, Nettilling Lake Burwash Bay, $65^{\circ} 57^{\prime} \mathrm{N}, 71^{\circ} 18^{\prime} \mathrm{W}$, August 9, 1986, S.G. Aiken 86-159, (CAN 518022), GIL_2421, KJ571311, KJ571230, M; Baffin Island, Pangnirtung, Cumberland Gulf, 66 ${ }^{\circ} 8^{\prime} \mathrm{N}, 65^{\circ} 41^{\prime} \mathrm{W}$, August 21-22, 1927, M.O. Malte 119180, (CAN 97644), - - -, -, F;

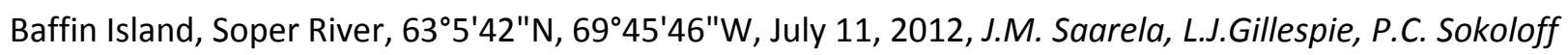
\& R.D.Bull 2317, (CAN 601957), GIL_2412, KJ571304, KJ571222, M; Baffin Island, Soper River, 63¹4'N, 69³7'W, July 4, 2012, J.M. Saarela, L.J.Gillespie, P.C. Sokoloff \& R.D.Bull 2075, (CAN 601958), GIL_2413, KJ571305, KJ571223, M; Baffin Island, Soper River, 6315'N, 69³5'W, July 19, 2012, J.M. Saarela, L.J.Gillespie, P.C. Sokoloff \& R.D.Bull 2057, (CAN 601955), GIL_2580, KJ571316, KJ571236, M; Bathurst Island, Bracebridge Inlet - south side, 5 miles east, -, July 12, 1973, S.D. MacDonald s.n., (CAN 416035), GIL_2637, KJ571328, KJ571252, M; Bathurst Island, Polar Bear Pass, Research Station, 7543' N, 98²5'W, August 7, 2000, L.J. Gillespie \& L.L. Consaul 6989, (CAN 586199), GIL_2414, KJ571306, KJ571224, M; Coats Island, East Coast, Keewatin District, 62 $49^{\prime} \mathrm{N}, 81^{\circ} 50^{\prime} \mathrm{W}$, September 19, 1930, A.E. Porsild 5935, (CAN 97662), -, -, -, F; Ellesmere Island, Alexandra Fiord, 7850' $\mathrm{N}, 76^{\circ} 25^{\prime} \mathrm{W}$, July 25,1996 , L.J. Gillespie \& C. Vogel 6181, (CAN 586184), GIL_2417, KJ571308, KJ571226, M; Ellesmere Island, Alexandra Fiord, $78^{\circ} 53^{\prime} \mathrm{N}, 75^{\circ} 45^{\prime} \mathrm{W}$, July 26, 1996, L.J. Gillespie \& C. Vogel 6167, (CAN 607182), GIL_2579, KJ571315, KJ571235, M; Ellesmere Island, Alexandra Fiord, $78^{\circ} 53^{\prime} \mathrm{N}, 75^{\circ} 50^{\prime} \mathrm{W}$, July 18, 1979, J.M. Gillett \& M.J. Schepanek 18248, (CAN 453948), GIL_2625, KJ571299, KJ571242, M; Ellesmere Island, Bache Peninsula, 794'N, 76¹8'W, July 31, 1927, M.O. Malte 119169, (CAN 97639), -, -, -, F; Ellesmere Island, Bjorne Peninsula, $77^{\circ} 37^{\prime} \mathrm{N}, 87^{\circ} 15^{\prime} \mathrm{W}$, July 30, 1961, C.R. Harrington 286, (CAN 270547), -, -, -, M; Ellesmere Island, Craig Harbour, 76 $12^{\prime} \mathrm{N}, 81^{\circ} 20^{\prime} \mathrm{W}$, August 2, 1927, M.O. Malte 119175, (CAN 97641), -, -, -, M; Ellesmere Island, Delta on E side of Lower Dumbell Lake, $82^{\circ} 26^{\prime} \mathrm{N}, 62^{\circ} 50^{\prime} \mathrm{W}$, July $8,1959, C . R$. Harrington 66, (CAN 261598), - , -, -, F; Ellesmere Island, Forsheim Peninsula, Hot Weather Creek, $79^{\circ} 58^{\prime} \mathrm{N}, 84^{\circ} 26^{\prime} \mathrm{W}$, July 20-21, 1996, L.J. Gillespie \& C. Vogel 6137-1, (CAN 585252), GIL_2582, KJ571318, KJ571237, M; Ellesmere Island, Fort Conger, Discovery Harbour, Franklin Bay, $81^{\circ} 45^{\prime} \mathrm{N}, 64^{\circ} 47^{\prime} \mathrm{W}$, July 30, 1984, N.R. Morrison and C.D. Rubec 7648, (CAN 490747), -, -, -, M; Ellesmere Island, Fosheim Peninsula, Hot Weather Creek, $79^{\circ} 58^{\prime} \mathrm{N}, 84^{\circ} 26^{\prime} \mathrm{W}$, July 19, 1996, L.J. Gillespie \& C. Vogel 6126, (-), GIL_2415, KJ571307, KJ571225, M; Ellesmere Island, Fosheim Peninsula, Slidre Fjord, $80^{\circ} 08^{\prime} \mathrm{N}, 86^{\circ} 20^{\prime} \mathrm{W}$, August 9, 1955, S.D. MacDonald 265, (CAN 235332), GIL_2638, KJ571329, KJ571253, M; Ellesmere Island, Hazen Camp, N Shore of Hazen Lake, $81^{\circ} 49^{\prime} \mathrm{N}, 71^{\circ} 20^{\prime} \mathrm{W}$, July 30, 1996, L.J. Gillespie \& C. Vogel 6240, (CAN 607189), GIL_2569, KJ571313, KJ571233, M; Ellesmere Island, Johan Peninsula, 7851'N, 7550'W, July 14, 1979, J.M. Gillett \& M.J. Schepanek 18146, (CAN 453879), GIL_2626, KJ571297, KJ571243, M; Ellesmere Island, Knud Peninsula, $79^{\circ} 02^{\prime} \mathrm{N}, 76^{\circ} 10^{\prime} \mathrm{W}$, July 17, 1979, J.M. Gillett 18233, (CAN 453940), GIL_2608, KJ571321, KJ571240, M; Ellesmere Island, Lake Hazen, $81^{\circ} 45^{\prime} \mathrm{N}, 82^{\circ} 10^{\prime} \mathrm{W}$, July 8, 1959, J.M. Powell 519, (CAN 483720), GIL_2624, KJ571322, KJ571241, M; Ellesmere Island, Lake Hazen vicinity, $81^{\circ} 45^{\prime} \mathrm{N}, 68^{\circ} 30^{\prime} \mathrm{W}$, July 4, 1959, J.M. Powell 508, (CAN 483722), GIL_2439, KJ571295, KJ571217, M; Ellesmere Island, 
Sverdrup Pass, $79^{\circ} 11^{\prime} \mathrm{N}, 79^{\circ} 25^{\prime} \mathrm{W}$, July 13, 1979, J.M. Gillett \& M.J. Schepanek 18062, (CAN 453815), GIL_2639, KJ571330, KJ571254, M; Ellesmere Island, Sverdup Pass, 7909'N, 79²5'W, July 17, 1979, J.M. Gillett 18190, (CAN 453906), GIL_2607, KJ571320, -, M; Ellesmere Island, Tanquary Fiord, 8100' N, 7945'W, July 21, 1964, G.R. Brassard 1584, (CAN 296315), - - -, -, M. GREENLAND: Melville Bugt, Tugtuligssuaq, $75^{\circ} 22^{\prime} \mathrm{N}, 58^{\circ} 32^{\prime} \mathrm{W}$, July 31,1979 , B. Fredskild \& C. Bay 658, (CAN 462393), GIL_2367, KJ571302, KJ571220, M; Qutdligssat, -, July 11, 1961, R.E. Beschel 12036, (CAN 274506), GIL_2368, KJ571303, KJ571221, M.

Pedicularis labradorica: CANADA: NUNAVUT: Belcher Islands, Sanikiluaq, $56^{\circ} 32^{\prime} \mathrm{N}, 79^{\circ} 123^{\prime} \mathrm{W}$, July 1 , 2010, L.L. Consaul, M. Ip \& D. Charette 3867, (CAN 599913), GIL_2373, KJ571371, KJ571289.

Pedicularis lanata: CANADA: NORTHWEST TERRITORIES: Paulatuk, $69^{\circ} 20^{\prime} \mathrm{N}, 124^{\circ} 2^{\prime} \mathrm{W}$, June 28,2009 , L.J. Gillespie, J.M. Saarela, L.L. Consaul \& R.D. Bull 8594, (CAN 595018), GIL_2437, KJ571375, KJ571293; Tuktoyuktuk, near end of road to sewage pond $~ 5 \mathrm{~km} \mathrm{~S}$ of town, 69 $26^{\prime} \mathrm{N}, 133^{\circ} 3^{\prime} \mathrm{W}$, July 23 1995, L.J. Gillespie 5936, (CAN 586714), GIL_2365, KJ571372, KJ571290. NUNAVUT: Baffin Island, Soper River, $62^{\circ} 59^{\prime} \mathrm{N}, 69^{\circ} 43^{\prime} \mathrm{W}$, July 15, 2012, J.M. Saarela, L.J.Gillespie, P.C. Sokoloff \& R.D.Bull 2479, (CAN 601952), GIL_2435, KJ571373, KJ571291; Ellesmere Island, Fosheim Peninsula, Hot Weather Creek, 7958'N, $84^{\circ} 26^{\prime}$ W, July 20-21, 1996, L.J. Gillespie \& C. Vogel 6134, (CAN 607188), GIL_2436, KJ571374, KJ571292; Ellesmere Island, Fosheim Peninsula, Hot Weather Creek, $79^{\circ} 58^{\prime} \mathrm{N}, 84^{\circ} 26^{\prime} \mathrm{W}$, July 20-21, 1996, L.J. Gillespie \& C. Vogel 6140, (CAN 586187), GIL_2438, KJ571376, KJ571294.

Pedicularis langsdorffii subsp. arctica: CANADA: NORTHWEST TERRITORIES: Atkinson Point, $70^{\circ} \mathrm{N}$, $131^{\circ} 20^{\prime}$ W, August 1-3, 1927, A. E. Porsild \& R.T. Porsild 2657, (CAN 97296), -, -, -, F; Banks Island, Aulavik National Park, $73^{\circ} 43^{\prime} \mathrm{N}, 119^{\circ} 55^{\prime} \mathrm{W}$, July 11, 1999, S.G. Aiken 99-054, (CAN 582445), GIL_2431, KJ571344, KJ571260, M; Banks Island, De Salis Bay, $71^{\circ} 28^{\prime} \mathrm{N}, 121^{\circ} 53^{\prime} \mathrm{W}$, July 21, 2003, L.J. Gillespie, H. Bickerton \& L. Consaul 7154-4, (CAN 586094), GIL_2592, KJ571351, KJ571273, M; Banks Island, lake near north east corner of island, $73^{\circ} 24^{\prime} \mathrm{N}, 117^{\circ} 00^{\prime} \mathrm{W}$, August 13-20, 1949, A.E. Porsild 17726, (CAN 128086), GIL_2633, KJ571369, KJ571287, M; Banks Island, Masik River Valley, $71^{\circ} 35^{\prime} \mathrm{N}, 125^{\circ} 8^{\prime} \mathrm{W}$, July 18, 2003, L.J. Gillespie, H. Bickerton \& L. Consaul 7136-4, (CAN 586096), GIL_2591, -, -, M; Banks Island, Masik River Valley, $71^{\circ} 35^{\prime} \mathrm{N}, 123^{\circ} 8^{\prime} \mathrm{W}$, July 18, 2003, L.J. Gillespie, H. Bickerton \& L. Consaul 7136-2, (CAN 586096), GIL_2370, KJ571334, KJ571265, M; Banks Island, Sachs Harbour south of Cape Kellett on S.W. coast, -, July 30th, 1949, A.E. Porsild 17529, (CAN 128085), GIL_2632, KJ571368, KJ571264, M; Banks Island, Shoran Lake, $73^{\circ} 31^{\prime} \mathrm{N}, 120^{\circ} 18^{\prime} \mathrm{W}$, July 19, 1971, K.L. Maclnnes s.n., (CAN 535590), GIL_2613, KJ571357, KJ571263, M; Cape Dalhousie, $70^{\circ} 20^{\prime} \mathrm{N}, 129^{\circ} 55^{\prime} \mathrm{W}$, August 7-14, 1927, A.E. Porsild \& R.T. Porsild 2793, (CAN 97305), -, -, -, F; Cape Dalhousie, 70²0'N, 12955'W, August 7-14, 1927, A.E. Porsild \& R.T. Porsild 2792, (CAN 97295), -, -, -, M; Eskimo Lake Basin, -, July 23, 1947, A.E. Porsild 16770, (CAN 97290), -, -, -, M; Inuvik, Anderson R. Delta, 69²4'N, $129^{\circ}$ W, June 29, 1963, T.W. Barry 57, (CAN 288024), GIL_2610, KJ571354, KJ571278, M; Liverpool Bay, Nicholson Island, 70N, 129 W, August 15-16, 1927, A.E. Porsild \& R.T. Porsild 2933, (CAN 97306), -, -, -, F; Liverpool Bay, Nicholson Island, 70N, 129 W, August 15-16, 1927, A.E. Porsild \& R.T. Porsild 2932, (CAN 97307), -, -, -, F; Liverpool Bay, Nicholson Island, 70'N, 129'W, August 15-16, 1927, A.E. Porsild \& R.T. Porsild 2931, (CAN 97304), -, -, -, M; Mackenzie Delta, North end of Richards Island, -, July 29-August 5, 1947, A.E. Porsild 16847, (CAN 97292), -, -, -, F; Mackenzie Delta, Tuktuyaktok, -, July 22, 1953, E.H. McEwen 100, (CAN 226151), GIL_2609, -, KJ571277, 
M; Mackenzie River delta, East branch, -, July 5, 1935, A.E. Porsild 7393, (CAN 97298), -, -, -, M; Mackenzie River Delta, $\mathrm{N}$ end of Richards Island, $69^{\circ} 40^{\prime} \mathrm{N}, 134^{\circ} 40^{\prime} \mathrm{W}$, July 22-24, 1947, A.E. Porsild 2274A, (CAN 97299), -, -, -, M; Melville Island, Bailey's Point, 744'N, 11440'W, July 19, 2004, A.A. Archambault 123, (CAN -), GIL_2601, -, -, -; Melville Island, Canrobert Hills, $75^{\circ} 57^{\prime} \mathrm{N}, 115^{\circ} 00^{\prime} \mathrm{W}$, July 25 th, 1984, S. Edlund 407, (CAN 489907), GIL_2618, GIL_2606, KJ571362, -, F; Melville Island, Ibbett Bay, -, July 20, 1961, J.S. Tener \& C.R.Harington 345, (CAN 270544), GIL_2619, KJ571363, -, M; Melville Island, Marie Bay, $76^{\circ} 15^{\prime} \mathrm{N}, 115^{\circ} 27^{\prime} \mathrm{W}$, July 23, 1985, S. Edlund 232, (CAN 495886), GIL_2616, KJ571360, KJ571282; , M Melville Island, Marie Bay, $76^{\circ} 12^{\prime} \mathrm{N}$, $114^{\circ} 55^{\prime} \mathrm{W}$, July 17th, 1984, S. Edlund 287, (CAN 489142), GIL_2617, GIL_2605, KJ571361, KJ571283, M; Melville Island, Murray Inlet, on Hecla Bay, $75^{\circ} 26^{\prime} \mathrm{N}, 113^{\circ} 30^{\prime} \mathrm{W}$, July 26, 1984, S. Edlund 421, (CAN 502397), GIL_2614, KJ571358, -, M; Melville Island, Shellabear Point, N side of Dundas Peninsula, $76^{\circ} 51^{\prime} \mathrm{N}, 113^{\circ} 23^{\prime} \mathrm{W}$, July 6, 1980, S. Edlund 022 , (CAN 486676), GIL_2615, KJ571359, KJ571281, M; Paulatuk, 69¹8'46"N, 12354'15"W, June 30, 2009, L.J. Gillespie, J.M. Saarela, L.L. Consaul \& R.D. Bull 8639, (CAN 595153), GIL_2596, -, -, F; Paulatuk, 69¹8'46"N, 12354'15"W, June 29, 2005, L.J. Gillespie, J.M. Saarela, L.L. Consaul \& R.D. Bull 8634, (CAN 595144), GIL_2371, KJ571335, KJ571266, M; Six miles E of Kittigazuit, 69²0'N, 133'W, July 24-28, 1927, A.E. Porsild \& R.T. Porsild 2518, (CAN 97294), -, -, -, F; Six miles E of Kittigazuit, 69²0'N, $133^{\prime} \mathrm{W}$, July $24-$ 28, 1927, A.E. Porsild \& R.T. Porsild 2519, (CAN 97293), -, -, -, M; Tuktuyaktok, 6940'N, $133^{\prime} \mathrm{W}$, Jult 25,

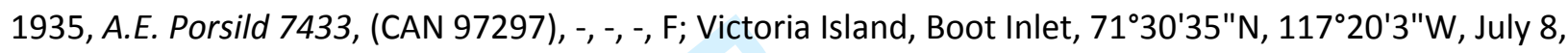
2010, L.J. Gillespie, J.M. Saarela, J. Doubt, R.D. Bull \& P.C. Sokoloff 9519-5, (CAN 599170), GIL_2372, KJ571336, KJ571267, M; Victoria Island, Minto Inlet, $71^{\circ} 12^{\prime} \mathrm{N}, 116^{\circ} 23^{\prime} \mathrm{W}$, July 14, 2010, L.J. Gillespie, J.M. Saarela, J. Doubt, R.D. Bull \& P.C. Sokoloff 9798, (CAN 599172), GIL_2599, -, -, M; Victoria Island, Minto Inlet, $71^{\circ} 31^{\prime} \mathrm{N}, 115^{\circ} 6^{\prime} \mathrm{W}$, July 25, 2010, L.J. Gillespie, J.M. Saarela, J. Doubt, R.D. Bull \& P.C. Sokoloff 10247, (CAN 599168), GIL_2602, -, -, -; Victoria Island, Minto Inlet, 71³7'N, 115²6'W, July 7, 2010, L.J. Gillespie, J.M. Saarela, J. Doubt, R.D. Bull \& P.C. Sokoloff 9479, (CAN 599169), GIL_2597, KJ571353, KJ571275, M; Victoria Island, S.W. coast, vicinity of Holman Island trading post., -, August 8th, 1949, A.E. Porsild 17330, (CAN 128087), GIL_2612, KJ571356, KJ571280, M; Victoria Island, Ulukhatok, 70N, $117^{\circ}$ W, July 6, 2010, J.M. Saarela \& R.D. Bull 1496, (CAN 599179), GIL_2600, -, KJ571276, M. NUNAVUT: Axel Heiberg Island, Gypsum Hill, $79^{\circ} 56^{\prime} \mathrm{N}, 87^{\circ} 14^{\prime} \mathrm{W}$, August 4, 1999, L.J. Gillespie, L.L. Consaul \& R.J. Soreng 6581, (-), GIL_2424, KJ571338, KJ571257,-; Devon Island, TrueLove Lowland, 7540'N, 8440'W, August 4, 1972, J. Kerik 40, (CAN 409447), GIL_2418, KJ571331, KJ571227, M; Ellesmere Island, Tanquary Camp, National Park Reserve, $81^{\circ} 24^{\prime} \mathrm{N}, 76^{\circ} 52^{\prime} \mathrm{W}$, July 21, 1999, L.J. Gillespie \& L.L. Consaul 6477, (-), GIL_2416, KJ571337, KJ571255, M; Ellesmere Island, Fosheim Peninsula, 7958' N, 84²6'W, July 20-21, 1996, L.J. Gillespie \& C. Vogel 6133, (CAN 585211), GIL_2589, -, -, -; Ellesmere Island, Fosheim Peninsula, Hot Weather Creek, $79^{\circ} 58^{\prime} \mathrm{N}, 84^{\circ} 26^{\prime} \mathrm{W}$, July 20-21, 1996, L.J. Gillespie \& C. Vogel 6139, (-), GIL_2369, KJ571333, KJ571256, M; Ellesmere Island, Fosheim Peninsula, Hot Weather Creek, $79^{\circ} 58^{\prime} \mathrm{N}, 84^{\circ} 26^{\prime} \mathrm{W}$, July 19, 1996, L.J. Gillespie \& C. Vogel 6125-2, (CAN 586292), GIL_2427, KJ571341, KJ571270, M; Ellesmere Island, Hazen Camp, $81^{\circ} 49^{\prime} \mathrm{N}, 71^{\circ} 20^{\prime} \mathrm{W}$, July 30, 1996, L.J. Gillespie \& C. Vogel 6239-1, (-), GIL_2428, KJ571342, KJ571258, M; Ellesmere Island, Hazen Camp, N Shore of Hazen Lake, $81^{\circ} 49^{\prime} \mathrm{N}$, $71^{\circ} 20^{\prime} \mathrm{W}$, July 30, 1996, L.J. Gillespie \& C. Vogel 6218-2, (CAN 586715), GIL_2588, KJ571349, -, -; Ellesmere Island, Mokka Fiord, river flowing into Bernard Lake, $79^{\circ} 29^{\prime} \mathrm{N}, 87^{\circ} 22^{\prime} \mathrm{W}$, July 15, 1996, L.J. Gillespie \& C. Vogel 6093, (-), GIL_2576, KJ571348, KJ571262, M; Ellesmere Island, Vendom Fiord, $78^{\circ} 02^{\prime} \mathrm{N}, 82^{\circ} 22^{\prime} \mathrm{W}$, July 11, 1973, P. Blachut \& S. Wilkins 32/31, (CAN 472947), GIL_2430, KJ571343, 
KJ571259, M; Melville Island, 5km from south central coastline, $74^{\circ} 54^{\prime} 17^{\prime \prime \prime} \mathrm{N}, 109^{\circ} 35^{\prime} 34^{\prime \prime} \mathrm{W}$, July 11 , 2009, L. Bosquet 27, (CAN 593622), GIL_2422, KJ571332, KJ571231, -; Melville Island, McCormick Inlet, $75^{\circ} 47^{\prime} \mathrm{N}, 112^{\circ} 26^{\prime} \mathrm{W}$, August 2, 2000, L.J. Gillespie \& L.L. Consaul 6960-3, (CAN 586205), GIL_2426, KJ571340, KJ571269, M; Prince Of Wales Island, South Inner Browne Bay, $73^{\circ} 8^{\prime} \mathrm{N}, 97^{\circ} 30^{\prime} \mathrm{W}$, July 5, 1958, E. Macpherson 220, (CAN 255633), GIL_2432, KJ571345, KJ571271, M; Queen Elizabeth Islands, Eglington Island, -, July 10, 1968, M. Kuc s.n., (CAN 331356), GIL_2611, KJ571355, KJ571279, M; Victoria Island, Johansen Bay, $68^{\circ} 39^{\prime} \mathrm{N}, 110^{\circ} 42^{\prime} \mathrm{W}$, July 13, 2008, L.J. Gillespie, J.M. Saarela, L.L. Consaul \& R.D. Bull 7896, (CAN 592802), GIL_2594, -, -, -; Victoria Island, Long Point Beach, 695'37"N, 105¹6'12"W, July 27, 2008, L.J. Gillespie, J.M. Saarela, L.L. Consaul \& R.D. Bull 8472, (CAN 592814), GIL_2425, KJ571339, KJ571268, M; Victoria Island, Oterkvik Point, 68³6'23"N, 112³4'7"W, July 4, 2008, L.J. Gillespie, J.M. Saarela, L.L. Consaul \& R.D. Bull 7507, (CAN 592392), GIL_2434, KJ571347, KJ571272, M; Victoria Island, Sinclair Creek, $68^{\circ} 43^{\prime} \mathrm{N}, 109^{\circ} 6^{\prime} \mathrm{W}$, July 22, 2008, L.J. Gillespie, J.M. Saarela, L.L. Consaul \& R.D. Bull 8287, (CAN 592806), GIL_2595, KJ571352, KJ571274, -. Axel Heiberg Island, Mokka Fiord, 79²9'N 87²2'W, July 15, 1996, L.J. Gillespie 6078, (CAN 607183), GIL_2574, -, -, -; Ellesmere Island, Tanquary Camp, 8124' N 76² 'W, July 29, 1996, L.J. Gillespie \& C. Vogel 6211, (CAN 607150), -, -, -, M; Ellesmere Island, Tanquary Camp, 812' $\mathrm{N} 76^{\circ} 52^{\prime} \mathrm{W}$, July 28, 1995, L.J. Gillespie \& F. Chatenoud 5954 (CAN 582567), -, -, -, M. YUKON: 3 miles S of Shingle Point, -, June 29, 1971, G. Ironside s.n., (CAN 375973), -, -, -, M; Between Bell River and Driftwood River, Western Richardson Mountains, 6755'N, $137^{\circ} 23^{\prime}$ W, June 30, 1973, S.L. Welsh \& J.K. Rigby 12309, (CAN 383370), GIL_2623, KJ571367, KJ571286, M; Clarence Lagoon, $69^{\circ} 36^{\prime} \mathrm{N}, 140^{\circ} 47^{\prime} \mathrm{W}$, July 9, 1990, L.L. Consaul \& S. G. Aiken 960, (CAN 550825), GIL_2622, KJ571366, -, M; Clarence Lagoon, 69³5'N, 14044'W, July 9, 1990, L.L. Consaul \& S.G. Aiken 989B, (CAN 550862), GIL_2621, KJ571365, KJ571285, M; Gladstone Creek Drainage, Ruby Range, $61^{\circ} 20^{\prime} \mathrm{N}, 138^{\circ} 37^{\prime} \mathrm{W}$, July 10, 1966, J.A. Neilson 752, (CAN 312169), -, -, , M -; Ivvavik National Park,

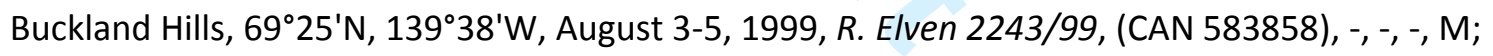
Mountain Slopes east of mouth of Slim's R., Kluane Lake, $60^{\circ} 57^{\prime} \mathrm{N}, 138^{\circ} 25^{\prime} \mathrm{W}$, July 18, 1944, H. M. \& L. G. Raup 12546, (CAN 277773), -, -, -, M; Vicinity of Alaska Highway Mile 837, 60³3'N, $133^{\circ} 6^{\prime} \mathrm{W}$, June 30, 1959, S.G. Shetler \& K.J. Stone 3100, (CAN 297421), GIL_2620, KJ571364, KJ571284, M.

Pedicularis langsdorffii subsp. arctica $\times$ Pedicularis hirsuta: CANADA: NUNAVUT: Axel Heiberg Island, Mokka Fiord, 7940'N, 8700'W, July 27, 1973, G. Parker 73061A (CAN 368203) , -,-,-, M; Devon Island, Truelove Inlet, $75^{\circ} 41^{\prime} \mathrm{N}, 84^{\circ} 40^{\prime} \mathrm{W}$, July 15, 1974, K. Mackenzie 14, (CAN 397501), -,-,-, M; Devon Island, Truelove Inlet, $75^{\circ} 41^{\prime} \mathrm{N}, 84^{\circ} 40^{\prime} \mathrm{W}$, July 16, 1974, K. Mackenzie 21, (CAN 397509), GIL_2433, KJ571346, KJ571261, M; Devon Island, Truelove Inlet, $75^{\circ} 41^{\prime} \mathrm{N}, 84^{\circ} 40^{\prime} \mathrm{W}$, July 21, 1974, K. Mackenzie 45, (CAN 397547), -,-,-, M; Devon Island, Truelove Lowland, $75^{\circ} 40^{\prime} \mathrm{N}, 84^{\circ} 40^{\prime} \mathrm{W}$, August 9, 1972, P. Pakarinen s.n. (CAN 409449), -,-,-, M; Ellesmere Island, Hot Weather Creek, $79^{\circ} 58^{\prime} \mathrm{N}, 84^{\circ} 26^{\prime} \mathrm{W}$, July 20-21, 1996, L.J. Gillespie \& C. Vogel 6138, (CAN 607185), GIL_2590, KJ571350,-, M; Ellesmere Island, Tanquary Camp, $81^{\circ} 24^{\prime} \mathrm{N}, 75^{\circ} 7^{\prime}$ W, July 21, 1999, L.J. Gillespie \& L.L. Consaul 6478 (CAN 607186), GIL_2571,-,- , M. 